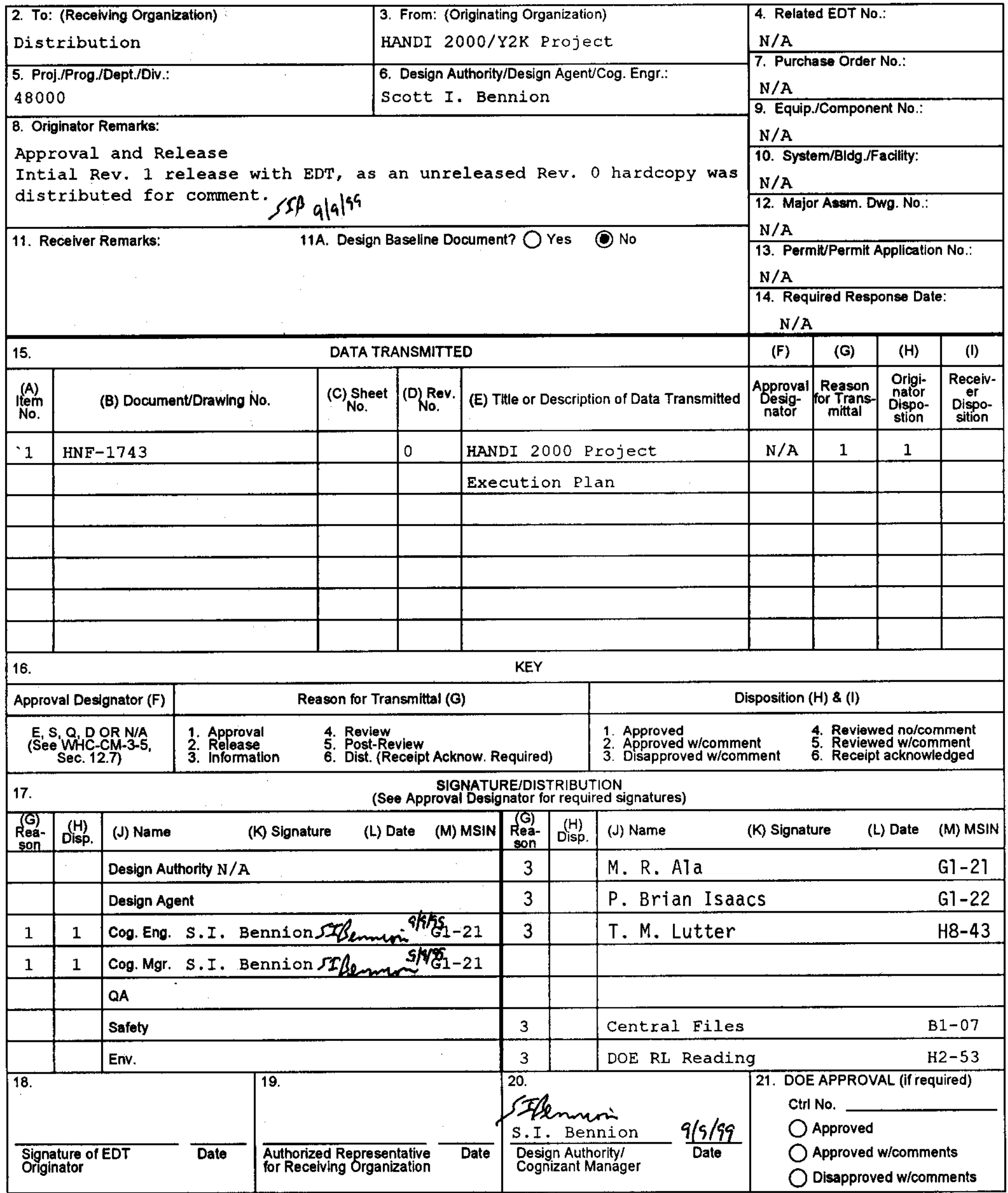




\title{
HANDI 2000 Project Execution Plan
}

\author{
S. I. Bennion \\ Fluor Daniel Hanford, Inc.
}

Richland, WA 99352

U.S. Department of Energy Contract DE-AC06-96RL13200

EDT/ECN: $E D T-627398 \quad$ UC: 900

Org Code: 48000

B\&R Code: EW7001000

Charge Code: HN9F0401 105753/AA30

Total Pages: 65

Key Words: HANDI 2000, H2K, COTS, PassPort, Project Execution Plan

\begin{abstract}
The HANDI 2000 project will meet some of the major objectives and goals of the PHMC Management and Integration Plan, HNF-MP-00, Rev. 11, by integrating the major Hanford business processes and their supporting information systems.

Indus Passport and Abacus are trademarks of Indus Group, Inc., The Peoplesoft is a trademark of Peoplesoft, Inc.

Primavera is a trademark of Primavera systems, Inc.
\end{abstract}

TRADEMARK DISCLAIMER. Reference herein to any specific commercial product, process, or service by trade name, trademark, manufacturer, or otherwise, does not necessarily constitute or imply its endorsement, recommendation, or tavoring by the United States Government or any agency thereof or its contractors or subcontractors.

Printed in the United States of America. To obtain copies of this document, contact: Document Control Services, P.O. Box 950, Mailstop H6-08, Richland WA 99352, Phone (509) 372-2420; Fax (509) 376-4989.
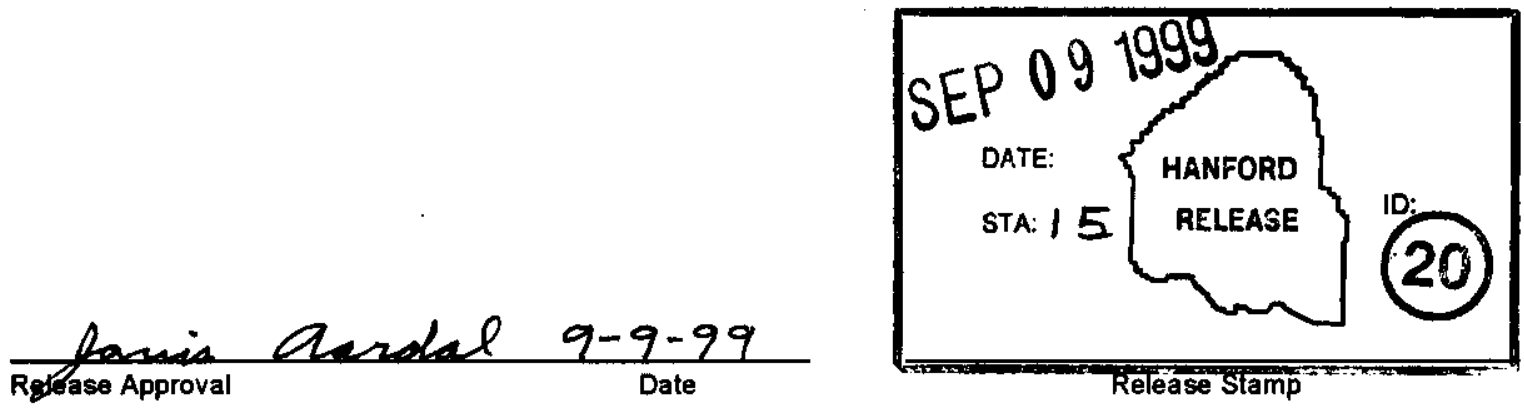

\section{Approved For Public Release}




\section{RECORD OF REVISION}

Page 1

(2) Titie

HANDI 2000 Project Execution Plan

Change Control Record

(3) Revision

(4) Description of Change - Replace, Add, and Delete Pages

(7)

1 RS Initial release per EDT-627398, as unreleased

Rev. 0 hardcopies were distributed for comment.
Authorized for Release

\begin{tabular}{l|ll} 
(5) Cog. Engr. & (6) Cog. Mgr. Date \\
\hline
\end{tabular}

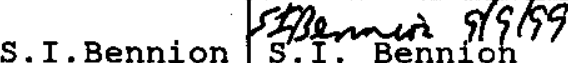


Project Name: HANDI 2000

Document Number: HNF-1743
Publication Date: November 5, 1997

Page: 1 of 63

Revision: 1

Fluor Daniel Hanford

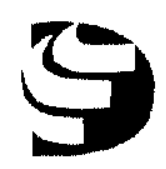

\section{HANDI 2000 PROJECT EXECUTION PLAN}

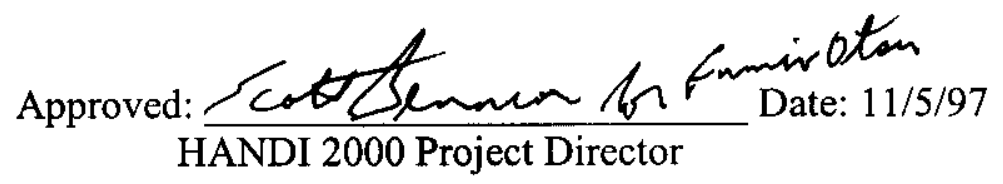


Project Name: HANDI 2000

Document Number: HNF-1743
Publication Date: November 5, 1997

Page: 2 of 63

Revision: 1

\section{TABLE OF CONTENTS}

INTRODUCTION ................................................................................................................................... 3

PROJECT SCOPE

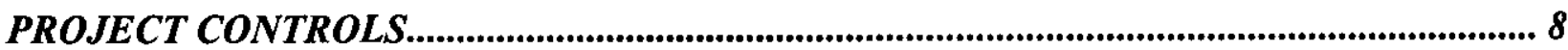

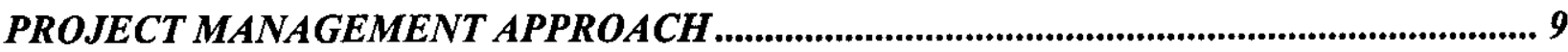

WORK BREAKDOWN STRUCTURE DICTIONARY ................................................... 11

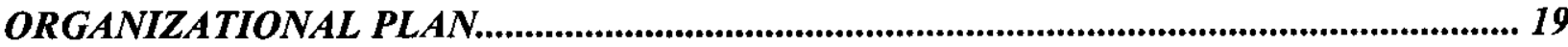

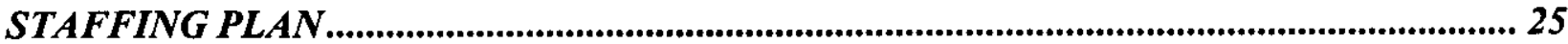

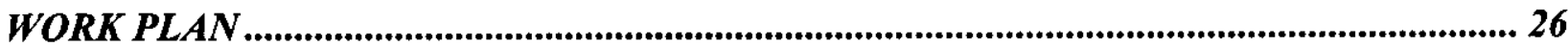

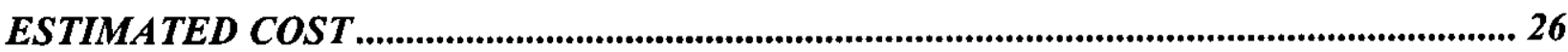

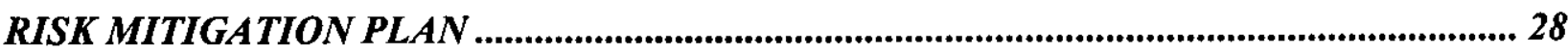

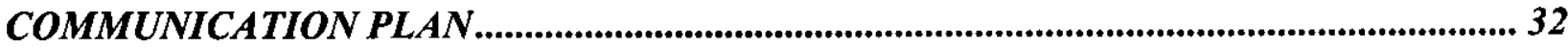

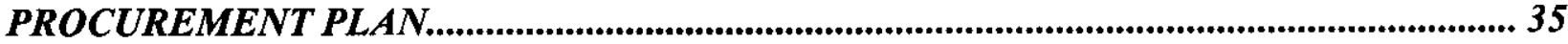

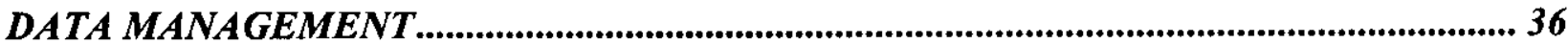

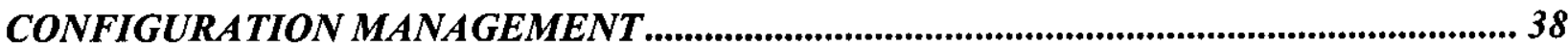

SYSTEM INTEGRATION AND ADMINISTRATION PLAN.......................................... 43

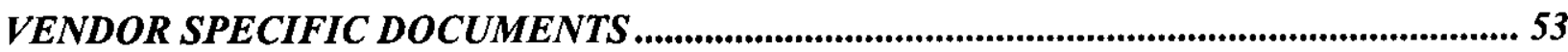

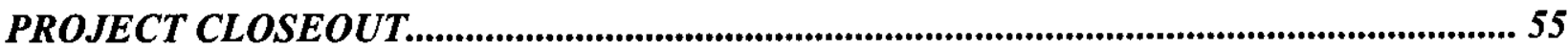

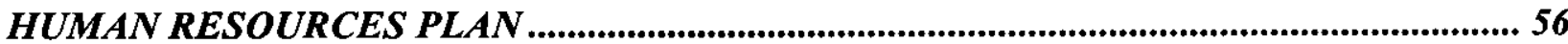

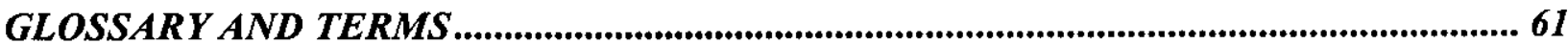


Project Name: HANDI 2000

Document Number: HNF-1743
Publication Date: November 5, 1997

Page: 3 of 63

Revision: 1

\section{INTRODUCTION}

The HANDI 2000 project will meet some of the major objectives and goals of the PHMC Management and Integration Plan HNF-MP-00, Revision 11, by integrating the major Hanford business processes and their supporting information systems. It will establish industry-standard work processes through business process enhancement and implementation of a set of integrated commercial off-the-shelf (COTS) enterprise resource planning (ERP) software products. This integration will reduce operating costs, improve productivity, and improve overall process integrity, and thus free more resources to focus on the site mission.

Business processes that will be affected are Project Management, Work Management, Financial Management, Supply Management, Human Resources, and Environmental, Safety, and Health.

The HANDI 2000 Project Execution Plan (PEP) included herein is the management level execution plan, that provides the overall structure and project direction for the HANDI 2000 project. This document with supporting subproject plans, and a companion vendor's implementation project plan will be used for project control and planning. Supporting subproject plans should be consulted for details about the individual portions of the project.

In some cases information in this plan will also be found in a subproject plan. Where conflicts exist between a subproject plan and this plan, this plan will take precedence. Whenever conflicts are noted, the Project Director and Subproject Manager should be promptly notified to resolve the conflict and to correct the appropriate plan.

The HANDI 2000 Project Director as assigned by FDH, is responsible for the preparation, review, approval, issuance, use, and revision of project specific management documents that create policy, establish plans, and prescribe work. The responsible Subproject Manager is accountable for ensuring that the document is technically correct and that implementation meets requirements, promotes safety, is cost effective, and reflects the applicable industry best practices.

1 M\&I Plan;Section;1.2 Success Criteria for PHMC Scope Accomplishment, 3.2.2 Baseline Performance Analysis, Reporting, and 3.5.4 Hanford Data Integrator Support, and 6.10 IRM System 
Project Name: HANDI 2000

Document Number: HNF-1743
Publication Date: November 5, 1997

Page: 4 of 63

Revision: 1

\section{PROJECT SCOPE}

The scope of this project includes improving core business processes, identification, assessing and remediation of system Year-2000 (Y2K) issues, and implementing the Financial and Budget, Supply Management, Project Management, Human Resources and Payroll, Action Tracking, and Document Management of the Passport/PeopleSoft Enterprise Resource Planning software system. Future HANDI 2000 systems such as Work Management and Safety and Compliance module will be included as they are approved for implementation.

\section{Deliverables for each module to be implemented include:}

Placing operational ERP software modules into production processing (e.g., backup, recovery, operational procedures, cost recovery/billing)

Retiring legacy systems whose functionality is replaced by Indus Passport/PeopleSoft functionality

Migrating necessary and sufficient data to the ERP software

Train the trainer programs (hands-on classroom or computer based)

Establishing a configuration control process to ensure continued managed process and data integrity

Project management and project reporting

\section{Project Objectives:}

The objective of the HANDI 2000 Project is to implement an integrated information resource management product set to recognize a positive return on investment within 3 years of implementation. The return on investment will be achieved through the integration of information, use of a common technology architecture, gained efficiencies in work processes, and the declining mortgage for maintaining the legacy software applications and interfaces at Hanford. The strategy is to use an integrated set of commercial off-the-shelf information technology products, and adopt widely applied industry work processes. Aligned with the DOERL Corporate Management Information Strategy, the HANDI 2000 Project will be managed with appropriate management control maintaining a focus and balance in three specific areas where a case for action exists: 
Project Name: HANDI 2000

Document Number: HNF-1743
Publication Date: November 5, 1997

Page: 5 of 63

Revision: 1

1. Redesign affected work processes through business process improvement.

2. Implement commercial off-the-shelf technology for application and standardize the desktop and central computing platform and operating environment

3. Define and control the data that is processed and interfaces between applications.

\section{Key Result Areas:}

To reduce maintenance, interface, and systems support costs for information resources.

To adopt widely accepted commercial industry business practices at Hanford

To have all mission critical systems with year 2000 vulnerabilities converted where possible to upgraded ERP type software by 1999

Improve operational discipline and overall data integrity

Reduce cost of data reconciliation 
Project Name: HANDI 2000

Document Number: HNF-1743
Publication Date: November 5, 1997

Page: 6 of 63

Revision: 1

\section{PROJECT BASIS}

The HANDI 2000 Project was planned and is proceeding on the following basis which provides the foundation for this Project Execution Plan (PEP) and its subordinate subproject plans. If any of the conditions in this baseline change, the project will need to be replanned or reviewed.

\section{Basis:}

This project is organized modularly and each process area will have its own case for action. This is to confirm the business needs for a module before resources are expended for implementation.

The HANDI 2000 system will serve PHMC Team companies. Enterprise companies are encouraged to implement compatible software in that they will be required to interface with the HANDI 2000 software in the prescribed formats.

Commercial off-the-shelf software (COTS) software will be utilized for all future system needs to minimize future maintenance and integration costs. Customization of the baseline software will be severely discouraged and controlled by a change board

Critical systems with year 2000 vulnerabilities will have priority considerations for replacement or remediation.

The integration of the software components (Indus Passport, PeopleSoft, and Primavera) will be supplied and maintained by a single integrating vendor.

Implementation of HANDI 2000 will be consistent with other site plans, including the Management and Integration Plan, and the Information Resource Management Plan, etc.

Funding will be provided for continuous implementation (i.e. without interruption until completion of each module) within the bounds of the yearly budgeting cycle.

Required resources (people, hardware, and facilities) will be available when needed. The project will be limited to existing PHMC Team facilities (i.e. no new locations are identified for this project).

The business case (financial justification White Paper) for implementing HANDI 2000 was calculated from ERP software vendor estimates of savings applied to projected Project budgets.

Required site infrastructure elements (network, desktop PC's, and ect.) will be available (based on FY98 annual work plan) and will support the HANDI 2000 schedule implementation/requirements.

ERP software technology is proven information technology, which can be applied to Hanford for a minimum of five to ten years. 
Project Name: HANDI 2000

Document Number: HNF-1743
Publication Date: November 5, 1997

Page: 7 of 63

Revision: 1

The long-term cost of residual mainframe computer operations for out-of-scope software systems was not considered in evaluating the business case.

The transformation to the HANDI 2000 integrated system will be a phased approach as systems are replaced and redundant systems are eliminated. Interim interfaces may be required to maintain system integrity throughout implementation phases. Parallel systems operations will be determined on a case-by-case basis for each module. 
Project Name: HANDI 2000

Document Number: HNF-1743
Publication Date: November 5, 1997

Page: 8 of 63

Revision: 1

\section{PROJECT CONTROLS}

\section{Estimates}

Fluor Daniel Hanford (FDH) will prepare cost estimates for the project life cycle and for Annual Work Plans (AWP) to obtain funding approval and manage the project. FDH will prepare a detailed cost estimate for each project during its implementation and execution phase.

\section{Cost}

The HANDI 2000 schedule, scope and budget will be managed with FDH management baseline control discipline, controlled by HANDI 2000 Project Integration and Controls.

\section{Schedules}

Fluor Daniel Hanford will develop a master schedule (see: work plan section) for the project containing the overall milestone requirements. To assist the initial development of the project, a front-end schedule will be utilized to follow and control the early work. During the front-end period an Integrated Resource Loaded Schedule and CPM Project Control Schedule will be developed for the execution of the project. Milestones will be established and will be controlled within established thresholds.

\section{Staffing and Progress}

This schedule will be resource loaded. This will enable physical progress and staffing plans to be generated for the project.

\section{Project Reporting}

The HANDI 2000 project will report progress, status and performance consistent with the requirements of Performance Reporting, HNF-MD-018. 
Project Name: HANDI 2000

Document Number: HNF-1743
Publication Date: November 5, 1997

Page: 9 of 63

Revision: 1

\section{PROJECT MANAGEMENT APPROACH}

The HANDI 2000 project management approach is highly integrated throughout all phases of implementation, while ensuring the final architecture meets the vision of commercial off the shelf software and commercial business practices. The approach is time phased to provide the return on investment within three years, and incorporates the issues of year-2000 impacts and yearly funding restraints.

\section{Project Direction and Support:}

- HANDI 2000 will be managed as a project, coordinated through the FDH Project Direction Group

- HANDI 2000 software modules will be implemented in a phased approach, and each module must provide a business case

- One vendor will be responsible for integrating all of the software modules

- HANDI 2000 implementation schedule will integrate the Year 2000 (Y2K) implementation plan

- Configuration control will be applied to module configuration data elements and business flow preferences

- A change board will maintain strict change control requirements for ERP Commercial of the Shelf (COTS) software applications and business practices

- A standard set of integrated common data elements will be developed for all HANDI 2000 software applications and business practices

- A common acceptance criteria will be used for each module prior to turn over to the process owner

- Other Hanford Prime Contractors (PNNL, Bechtel, and HEHF) will be accommodated for information requirements feeds supplied by these companies as they currently exist

- The integrity of existing information interfaces and data feeds to Other Hanford Contractors (PNNL, Bechtel, ect.) will be maintained

\section{Project Management:}

- Primavera (P3) is the site scheduling tool to be used by PHMC team, and will be integrated into the Integrated Site Baseline

- The HANDI system will be used to report performance, until HANDI 2000 systems are fully evaluated for applicability and implementation

- HANDI 2000 project management software modules will be implemented with Work Management if both are approved for implementation

- Beginning FY 99 PeopleSoft Financial will feed the performance module for the P3 schedule and performance measurement process 
Project Name: HANDI 2000

Document Number: HNF-1743

\section{Human Resources}

- Existing PeopleSoft Human Resources Functions will be upgraded to the current version of the finance and supply management system to be implemented

\section{Work Management:}

- If approved for implementation, Work Management modules will be piloted before Sitewide implementation; the pilot will be Tank Waste Remediation System (TWRS) Project.

- Action Tracking, including deficiency tracking system (DTS) will be implemented for all of the PHMC Team

- HANDI 2000 Project will provide facilitation for business process improvement redesign (AS-IS/TO-BE); impacted business units will provide staff to perform redesign, and implementation support

- Engineering Change Control (future), Document Management, and Labor Entry (future) modules will be implemented for all of the PHMC Team

\section{Financial \& Supply Management}

- PeopleSoft Financial and Indus Passport supply management system will be implemented for all of the PHMC Team

- The financial and supply management system will be implemented to cut-over at the beginning of fiscal year 1999

- Implementing supply management module may require operating parallel supply management system for a period of time to be determined by the implementation team

\section{Environmental, Safety, \& Health}

- A business case will be developed for each module prior to implementation

- Personnel Qualification module will be implemented in conjunction with work management, due to their strong inter-dependencies

\section{Year 2000 (Y2K)}

- Y2K non-compliant system renewal and or replacement will be prioritized by highest risk

- Major Sub-Contractors will be responsible for assuring their systems and equipment are Y2K compliant

- Y2K project progress will be reported separately to Department of Energy Headquarters (DOE HQ) each quarter

- Each system or equipment will be evaluated through a certification process regardless if it is Y2K compliant

\section{Business Process Improvement}

- Process redesigns will be integrated, the business processes will adopt business practices inherent to the COTS software 
Project Name: HANDI 2000

Document Number: HNF-1743
Publication Date: November 5, 1997

Page: 11 of 63

Revision: 1

\section{WORK BREAKDOWN STRUCTURE DICTIONARY}

The Work Breakdown Structure (WBS) for HANDI 2000 represents the project management approach and scope of the project. The WBS for each subproject reflects the deliverables and accountability to ensure project success.

\subsection{Project Direction \& Support}

\subsubsection{Project Direction}

Organize the project management and support team; define membership, roles and responsibilities, interface relationships, and charters. Develop a project plan which documents the HANDI 2000 project implementation strategy, assumptions, project integration, Y2K integration, and management controls, and includes a total project resource loaded implementation schedule.

\subsubsection{Project Integration}

Provide management support, project planning and scheduling, and program control. Develop a communications plan for the project. Refine and validate the project schedule after the vendorfacilitated workshop. Define requirements of integration; hold subprojects accountable to deliverables satisfying these requirements

\subsubsection{Project Configuration Control}

Ensure information and technology integration within the project. This element includes the technical support to establish hardware and software infrastructure requirements, and acquire required hardware and software, and the technical support for installation, and initial training. This task also includes the planning for legacy systems migration. The configuration management program is developed within this element to provide common management controls, discipline, and tools throughout the HANDI 2000 functional implementation phases.

\section{$1.2 \quad$ Project Management Modules}

\subsubsection{Project Controls}

Provide project management leadership. Perform day to day project management functions to track progress against planned schedule, actual costs against budget, and control work scope. Resolve conflicts/issues quickly to promote a rapid implementation. Coordinate with HANDI 2000 project configuration control to maintain specified controls and assure necessary integration. 
Project Name: HANDI 2000

Document Number: HNF-1743

1.2.2 Project Management Module

The implementation detail for the Project Management modules is provided in the original Baseline Change Request submittal, "Enterprise Resource Planning Project, ERP-97-001, as Attachment 2, "Fluor Daniel Hanford Site Scheduling System \& Standards Implementation Plan", dated April 16, 1997.

\subsubsection{Project Integration}

Coordinate the teams involved with implementing project management modules, and integrating the project scheduling software (P3)

\subsubsection{HANDI System}

This element is to provide for coordination and integration of the HANDI system effort with the HANDI 2000 effort.

\subsubsection{P3 Conversion}

This element is to coordinate the P3 conversion from PX with the HANDI 2000 effort.

\subsection{Work Management}

\subsubsection{Project Controls}

Provide project management leadership. Perform day to day project management functions to track progress against planned schedule, actual costs against budget, and control work scope. Resolve conflicts/issues quickly to promote a rapid implementation. Execute the data management plan, develop a case-for-action and where the business case exists, redesign the work process and implement appropriate PASSPORT Work Management modules. . Coordinate with HANDI 2000 project configuration control to maintain specified controls and assure necessary integration.

\subsubsection{Work Management (If approved for implementation)}

Work Management module implementation. Implementation to include installation, business process improvement, testing, training, and start-up.

\subsubsection{Engineering Change Control (If approved for implementation)}

Engineering Change Control module implementation. Implementation to include installation, business process improvement, testing, training, and start-up.

\subsubsection{Document Management}

Document Management module implementation. Implementation to include installation, business process improvement, testing, training, and start-up. 
Project Name: HANDI 2000

Document Number: HNF-1743

\subsubsection{Action Tracking}

Action Tracking module implementation. Implementation to include installation, business process improvement, testing, training, and start-up.

1.3.6 Labor Entry and Reporting (If approved for implementation)

Labor Entry \& Reporting functions as they relate to work management implementation.

Implementation to include installation, business process improvement, testing, training, and startup.

\subsection{Financial \& Procurement Modules}

\subsubsection{Project Start-Up}

Document the business case, define the scope, obtain funding, identify team sponsors and members, develop the project organization, define roles and responsibilities, and develop the project execution plan, configuration management plan, data management plan, and communications plan.

\subsubsection{Infrastructure Preparation}

Define infrastructure requirements; acquire hardware and software as necessary to support the Finance and Supply Management subproject in context with HANDI 2000 requirements. Define team desktop resources required to implement the project. Develop a desktop management plan to support the scope of this subproject.

\subsubsection{Financial Management Phase I}

Implement the first phase of Finance Management to include General Ledger, Budget, Project Costing and Accounts Payable.

\subsubsection{Supply Management}

Implement the Supply Management functions to include Purchasing, Inventory, Contracts Management and Accounts Payable.

\subsubsection{Financial Management Phase II}

Implement Phase II of Finance Management to include Accounts Receivable, Billings (if applicable), and Asset Management.

\subsubsection{Project Control}

Provide project management leadership. Perform day to day project management functions to track progress against planned schedule, actual costs against budget, and control work scope. Resolve conflicts/issues quickly to promote a rapid implementation. Coordinate with HANDI 2000 project configuration control to maintain specified controls and assure necessary integration.

\subsection{Human Resources Module}


Project Name: HANDI 2000

Document Number: HNF-1743
Publication Date: November 5, 1997

Page: 14 of 63

Revision: 1

\subsubsection{Project Controls}

Provide project management leadership. Perform day to day project management functions to track progress against planned schedule, actual costs against budget, and control work scope. Resolve conflicts/issues quickly to promote a rapid implementation. Coordinate with HANDI 2000 project configuration control to maintain specified controls and assure necessary integration.

\subsubsection{PeopleSoft HR System}

Upgrade the current HR PeopleSoft software and work processes to integrate with the other HANDI 2000 products.

\subsubsection{Payroll}

Payroll module implementation. Implementation to include installation, business process improvement, testing, training, and start-up.

\subsubsection{Time \& Labor}

Time \& Labor implementation. Implementation to include installation, business process improvement, testing, training, and start-up.

\subsubsection{Pension Administration}

Pension Administration module implementation. Implementation to include installation, business process improvement, testing, training, and start-up.

\subsubsection{Benefits Administration}

Benefits Administration implementation. Implementation to include installation, business process improvement, testing, training, and start-up.

\subsection{ES\&H Modules (If approved for implementation)}

\subsubsection{Project Controls}

Document the business case, define the scope, obtain funding, identify team sponsors and members, develop the project organization, define roles and responsibilities, and develop the project execution plan, configuration management plan, data management plan, and communications plan. Coordinate with HANDI 2000 project configuration control to maintain specified controls and assure necessary integration.

\subsubsection{Personnel \& Qualification Data}

Personnel \& Qualification Data module implementation. Implementation to include installation, business process improvement, testing, training, and start-up

\subsubsection{MSDS}

MSDS module implementation. Implementation to include installation, business process improvement, testing, training, and start-up 
Project Name: HANDI 2000

Document Number: HNF-1743

\subsubsection{Equipment Tag Out}

Equipment Tag Out module implementation. Implementation to include installation, business process improvement, testing, training, and start-up

\subsubsection{Total Exposure/Health Physics}

Total Exposure/Health Physics module implementation. Implementation to include installation, business process improvement, testing, training, and start-up.

\subsubsection{Emissions Tracking}

Emissions Tracking module implementation. Implementation to include installation, business process improvement, testing, training, and start-up

\subsection{Year 2000}

\subsubsection{Impact Identification}

Identify applications and equipment systems and infrastructure components with potential Year 2000 impacts. This identification includes risk ranking of the mission essential impacts. Information will be gathered during this phase for the assessment phase to assist in understanding the skills and tools needed to perform remediation and related technical infrastructure needs.

\subsubsection{Assessment}

Detailed assessments will gather sufficient information about a 'project' to determine what type of solution (repair, replace, or eliminate) should be implemented. The assessor will divide the work effort into manageable units and provide a plan for remediation and implementation.

\subsubsection{Remediation}

Remediation is the actual work involved in modification or conversion of a system or component for Year 2000 compliance. Remediation utilizes system development methodologies to remediate and migrate the compliant solutions into the client's production environment. Testing methodologies support thorough unit, system, integration, and acceptance testing.

\subsubsection{Compliance Certification}

Certify that PHMC remediation projects meet compliance standards and requirements. All identified components must function effectively up to and into the next century. The validation process involves complete system testing, including the associated infrastructure, equipment and external interfaces that are identified as components of the system. Certification ensures that compliance efforts are documented and can be validated. Certification is accomplished independent of remediation so that proper controls can be maintained.

\subsubsection{Project Planning \& Control}

Project control and support encompasses the activities of overall project management and integration, project planning and control, maintaining a Year 2000 data repository, project document control, educate, raise visibility and appraise site of Year 2000 efforts and status, 
Project Name: HANDI 2000

Document Number: HNF-1743
Publication Date: November 5, 1997

Page: 16 of 63

Revision: 1

providing a controlled environment for assessment and remediation, and technical consulting. Project reporting will follow the formats for Hanford direct projects. Coordinate with HANDI 2000 with regards to legacy system disposition and replacement system implementation plans. 
Project Name: HANDI 2000

Document Number: HNF-1743

WBS Structure

\section{HANDI 2000 Project}

1.1 Project Direction \& Integration

1.1.1 Project Direction

1.1.2 Project Integration

1.1.3 Project Configuration Control

\subsection{Project Management Modules}

1.2.1 Project Controls

1.2.2 Project Management Module

1.2.3 Project Integration

1.2.4 HANDI System

1.2.5 P3 Conversion

\subsection{Work Management Modules}

1.3.1 Project Controls

1.3.2 Work Management

1.3.3 Engineering Change Control

1.3.4 Document Management

1.3.5 Action Tracking

1.3.6 Labor Entry \& Reporting

1.4 Finance \& Supply Modules

1.4.1 Project Start-up

1.4.2 Infrastructure Preparation

1.4.3 Financial Management Phase I

1.4.4 Supply Management

1.4.5 Financial Management Phase II

1.4.6 Project Control

\subsection{Human Resources}

1.6.1 Project Controls

1.6.2 PeopleSoft HR System

1.6.3 Payroll

1.6.4 Time \& Labor

1.6.5 Pension Administration

1.6.6 Benefits Administration
Publication Date: November 5, 1997

Page: 17 of 63

Revision: 1

$\underline{\text { RL WBS Number }}$

6.1.4.4.1

6.1.4.4.1.1

6.1.4.4.1.1

6.1.4.4.1.1

6.1.4.4.1.3

6.1.4.4.1.1 
Project Name: HANDI 2000

Document Number: HNF-1743

\section{$1.7 \quad$ ES\&H}

1.7.1 Project Controls

1.7.2 Personnel \& Qualification Data

1.7.3 MSDS

1.7.4 Equipment Tag Out

1.7.5 Total Exposure/Health Physics

1.7.6 Emissions Tracking

$1.8 \quad$ Y2K

1.8.1 Impact Identification

1.8.2 Assessment

1.8.3 Remediation

1.8.4 Compliance Certification

1.8.5 Project Planning \& Control
Publication Date: November 5, 1997

Page: 18 of 63

Revision: 1
6.1.4.4.1.1

6.1.4.4.1.2 


\section{ORGANIZATIONAL PLAN}

\section{HANDI 2000 PROJECT ORGANIZATION}

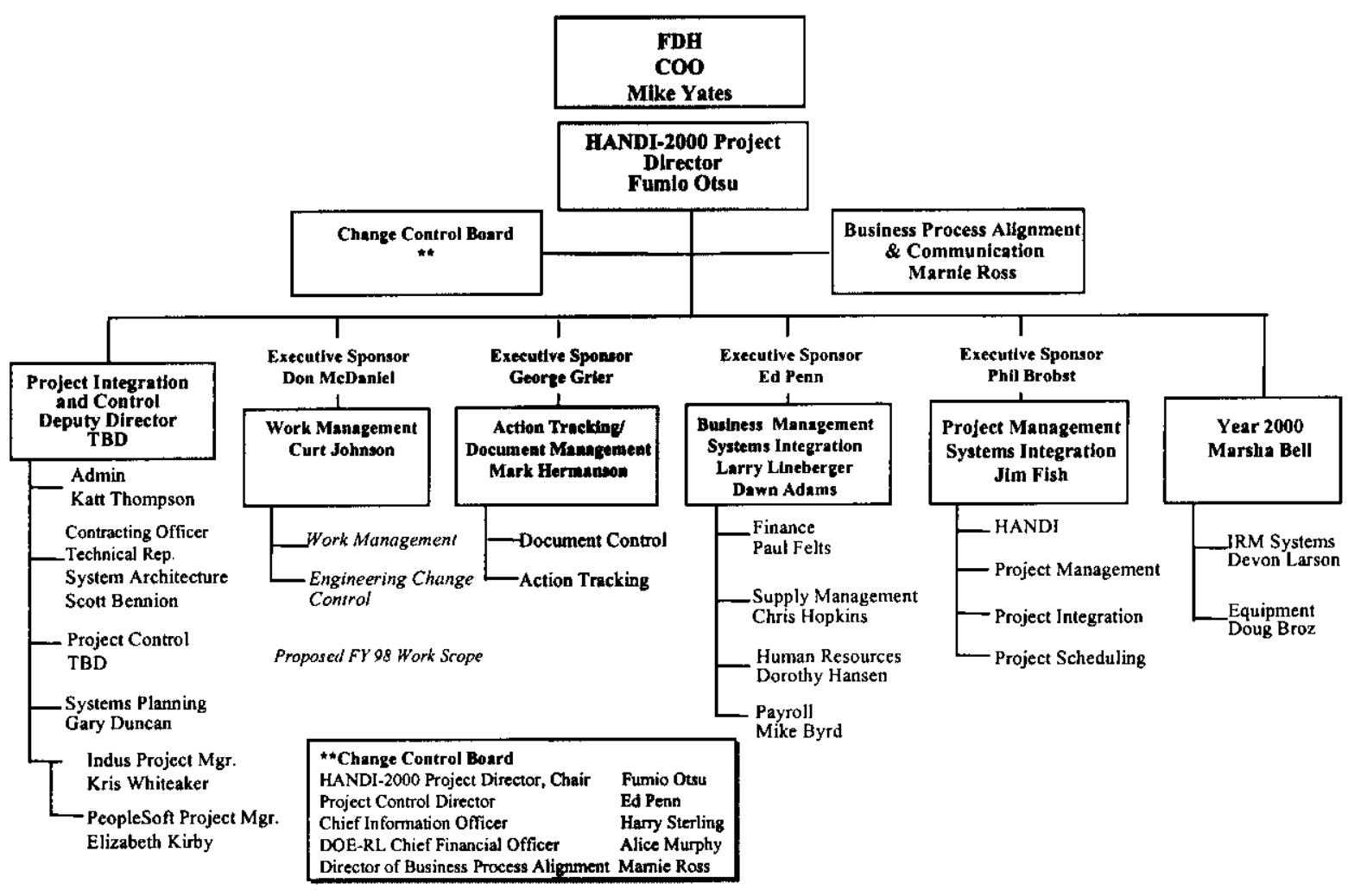

The organizational plan represents the structure required to fully execute the 1998 scope of work described in the HANDI 2000 PEP. This organization aligns with the sub project concepts of the work breakdown structure where each sub project has a budget and schedule baseline to measure progress and performance. Each sub project manager will have accountability in meeting the objects of the work plan.

The Project Director has the responsibility to maintain integration between all of the sub projects to preserve the overall HANDI 2000 architecture. This function ensures the final HANDI 2000 system will fully integrated for current transitional and final systems. The sub project managers have full responsibility and accountability for their scope of work. This includes schedule, budget and quality issues. In addition, they have full responsibility for integration of their functional system to existing systems. Executive Sponsors provides management oversight for each subproject based on their functional responsibilities. This allows each subproject to receive timely decision making and guidance. 
Project Name: HANDI 2000

Document Number: HNF-1743
Publication Date: November 5, 1997 Page: 20 of 63

Revision: 1

The change board will have responsibility to approve all changes to the HANDI 2000 cots software. This ensures the costs for implementation will be maintained within the allocated funds and the long term advantages of COTS. This change board will change membership as the functional focus of the scope of work for implementation changes and evolves. 
Project Name: HANDI 2000

Document Number: HNF-1743

Responsibility Assignment Matrix
Publication Date: November 5, 1997 Page: 21 of 63

Revision: 1

\begin{tabular}{|c|c|c|c|c|c|c|c|c|c|c|}
\hline $\begin{array}{l}\text { Legend } \\
\text { A: Accountable } \\
\text { S: Scope Change Authority } \\
\text { R: Review } \\
\text { P: Participant } \\
\text { I: Information }\end{array}$ & 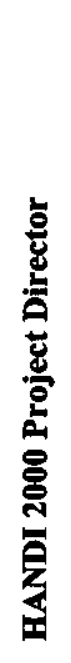 & 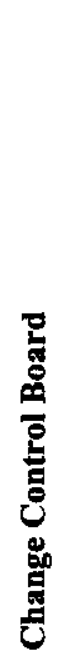 & 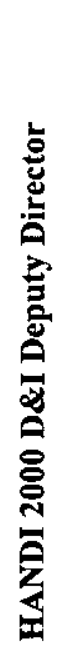 & 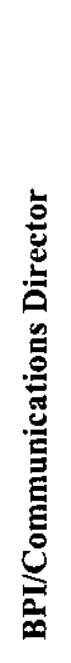 & 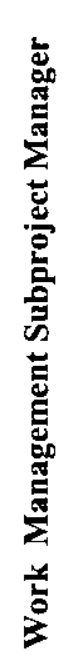 & 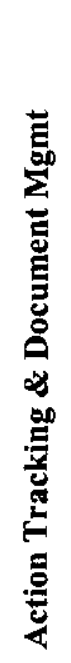 & 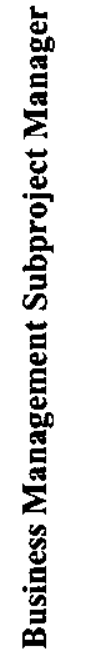 & 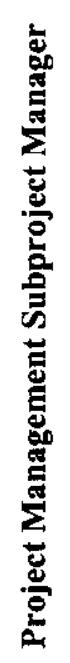 & 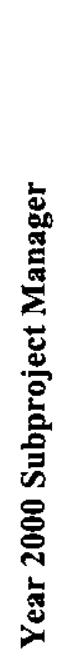 & 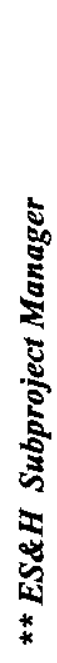 \\
\hline \multicolumn{11}{|c|}{ 1. 1 Project Direction \& Integration } \\
\hline 1.1.1 Project Direction & A & $\mathrm{S}$ & $\mathrm{P}$ & I & I & I & I & I & I & I \\
\hline 1.1.2 Project Integration & $\mathbf{R}$ & $\mathrm{S}$ & A & $\mathrm{P}$ & $\mathbf{P}$ & $\mathbf{P}$ & $P$ & $\mathrm{P}$ & $\mathrm{P}$ & I \\
\hline 1.1.3 Project Configuration Control & $\mathbf{R}$ & S & A & $I$ & $\mathrm{P}$ & $\mathrm{P}$ & $\mathbf{P}$ & $\mathbf{P}$ & $P$ & $\mathbf{P}$ \\
\hline \multicolumn{11}{|c|}{ 1.2 Project Management Modules $\quad$ (n) } \\
\hline 1.2.1 Project Controls & $\mathbf{R}$ & $\mathrm{S}$ & 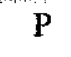 & $P$ & & & & A & & \\
\hline 1.2.2 Project Management Module & $\mathbf{R}$ & S & $\mathbf{P}$ & I & $P$ & $P$ & $\mathbf{P}$ & A & I & I \\
\hline 1.2.3 Project Integration & $\mathbf{R}$ & S & $\mathbf{P}$ & $\mathrm{P}$ & $\mathrm{P}$ & $\mathbf{P}$ & $\mathrm{P}$ & A & I & I \\
\hline 1.2.4 HANDI System & $\mathbf{R}$ & $\mathrm{S}$ & $\mathrm{R}$ & $P$ & I & & $\mathbf{P}$ & A & & \\
\hline 1.2.5 P3 Conversion & $\mathbf{R}$ & $\mathbf{S}$ & $\mathrm{R}$ & $\mathrm{P}$ & I & & I & A & & \\
\hline \multicolumn{11}{|c|}{ 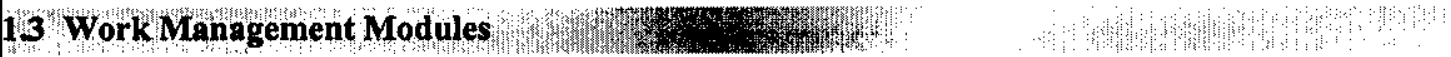 } \\
\hline 1.3.1 Project Controls & $\mathbf{R}$ & $\mathrm{S}$ & $\mathrm{R}$ & $P$ & A & $\mathrm{P}$ & & & & \\
\hline 1.3.2 Work Management & $\mathbf{R}$ & $\mathrm{S}$ & I & $\mathrm{P}$ & A & $P$ & I & $P$ & I & I \\
\hline 1.3.3 Engineering Change Control & $\mathbf{R}$ & $\mathrm{S}$ & I & $P$ & A & $\mathbf{P}$ & $\mathbf{I}$ & I & I & \\
\hline 1.3.4 Document Management & $\mathbf{R}$ & $s$ & I & $P$ & $P$ & A & $\mathbf{I}$ & I & I & \\
\hline 1.3.5 Action Tracking & $\mathbf{R}$ & $\mathrm{s}$ & I & $\mathbf{P}$ & $P$ & A & I & I & I & \\
\hline 1.3.6 Labor Entry \& Reporting & $\mathbf{R}$ & $S$ & I & $\mathbf{P}$ & A & $\mathbf{P}$ & $\mathrm{P}$ & I & I & I \\
\hline \multicolumn{11}{|c|}{1.4 Finance \& Supply Modules } \\
\hline 1.4.1 Project Start-Up & $\mathbf{R}$ & $\mathrm{S}$ & I & $\mathbf{P}$ & & & A & & & \\
\hline 1.4.2 Infrastructure Preparation & $\mathbf{R}$ & $\mathrm{S}$ & I & & I & I & A & I & I & \\
\hline 1.4.3 Financial Management Phase I & $\mathbf{R}$ & S & I & $\mathrm{P}$ & I & I & A & I & I & \\
\hline 1.4.4 Supply Management & $\mathbf{R}$ & $S$ & I & $\mathrm{P}$ & I & I & A & I & I & \\
\hline 1.4.5 Financial Management Phase II & $\mathbf{R}$ & s & I & $\mathrm{P}$ & $\mathrm{I}$ & I & A & I & I & \\
\hline 1.4.6 Project Control & $\mathbf{R}$ & $\mathrm{S}$ & $\mathrm{R}$ & & & & A & & & \\
\hline
\end{tabular}


A: Accountable

S: Scope Change Authority

R: Review

P: Participant

I: Information

\subsection{Human Resources Modules}

1.6.1 Project Controls

1.6.2 PeopleSoft HR System

1.6.3 Payroll

1.6.4 Time and Labor

1.6.5 Pension Administration

1.6.6 Benefits Administration

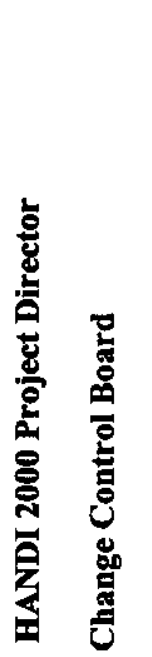

1.7 ES\&H Modules

1.7.1 Project Controls

1.7.2 Personnel \& Qualification Data

1.7.3 MSDS

1.7.4 Equipment Tag Out

1.7.5 Total Exposure/Health Physics

1.7.6 Emissions Tracking

$\begin{array}{lll}R & S & R\end{array}$

R $\quad S \quad I$

R S

R S

R S

R S

$$
\mathrm{P}
$$

$\mathrm{A}$

A

A

A I I P

A I I

A $\quad$ I I I I

A I I

I

$18 \mathrm{Y} 2 \mathrm{~K}$

1.8.1 Impact identification

$\begin{array}{lll}\mathbf{R} & \mathbf{S} & \mathbf{R}\end{array}$

$\begin{array}{llllll}R & S & \text { I } & P & P & \text { I }\end{array}$

$\begin{array}{llllll}R & S & I & P & P & I\end{array}$

$\begin{array}{llllll}\mathbf{R} & \mathrm{S} & \mathrm{I} & \mathrm{P} & \mathrm{P} & \mathrm{I}\end{array}$

$\begin{array}{llllll}R & S & I & P & P & \text { I }\end{array}$

$\begin{array}{lllll}R & S & \text { I } & P & \text { I }\end{array}$

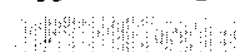

1.8.2 Assessment

R S

1.8.3 Remediation

R S

R S

R S

R $\quad \mathrm{S} \quad \mathrm{R}$ 
Project Name: HANDI 2000

Document Number: HNF-1743
Publication Date: November 5, 1997

Page: 23 of 63

Revision: 1

\section{STAFFING PLAN}

Fluor Daniel Hanford, Inc. will utilize the centralized project concept under one Project Director solely responsible to both Department of Energy and Fluor Daniel Hanford management for the planning, organizing, directing, and coordinating of the project. Matters relating to the execution of this project will be coordinated with Department of Energy Project Manager.

As the works develops, personnel will be mobilized full time on the project.

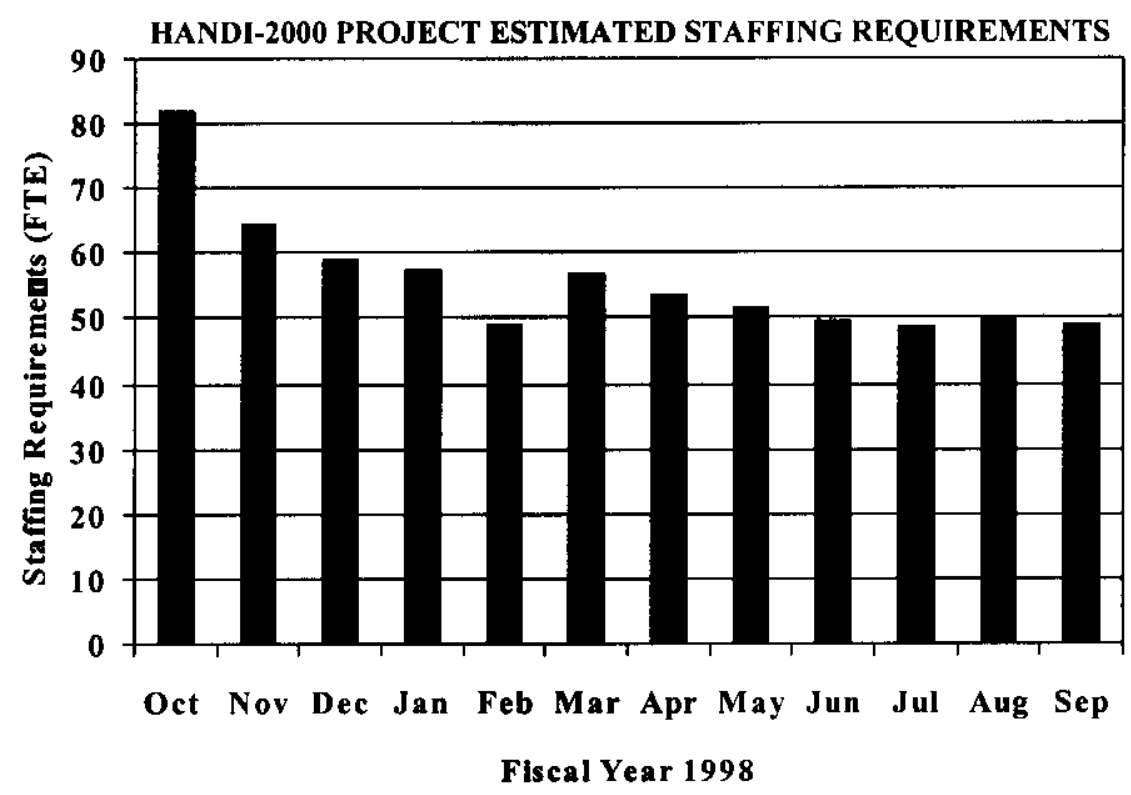


Project Name: HANDI 2000

Document Number: HNF-1743
Publication Date: November 5, 1997

Page: 24 of 63

Revision: 1

\section{WORK PLAN}

\section{HANDI-2000 PROJECT WBS SUMMARY SCHEDULE}

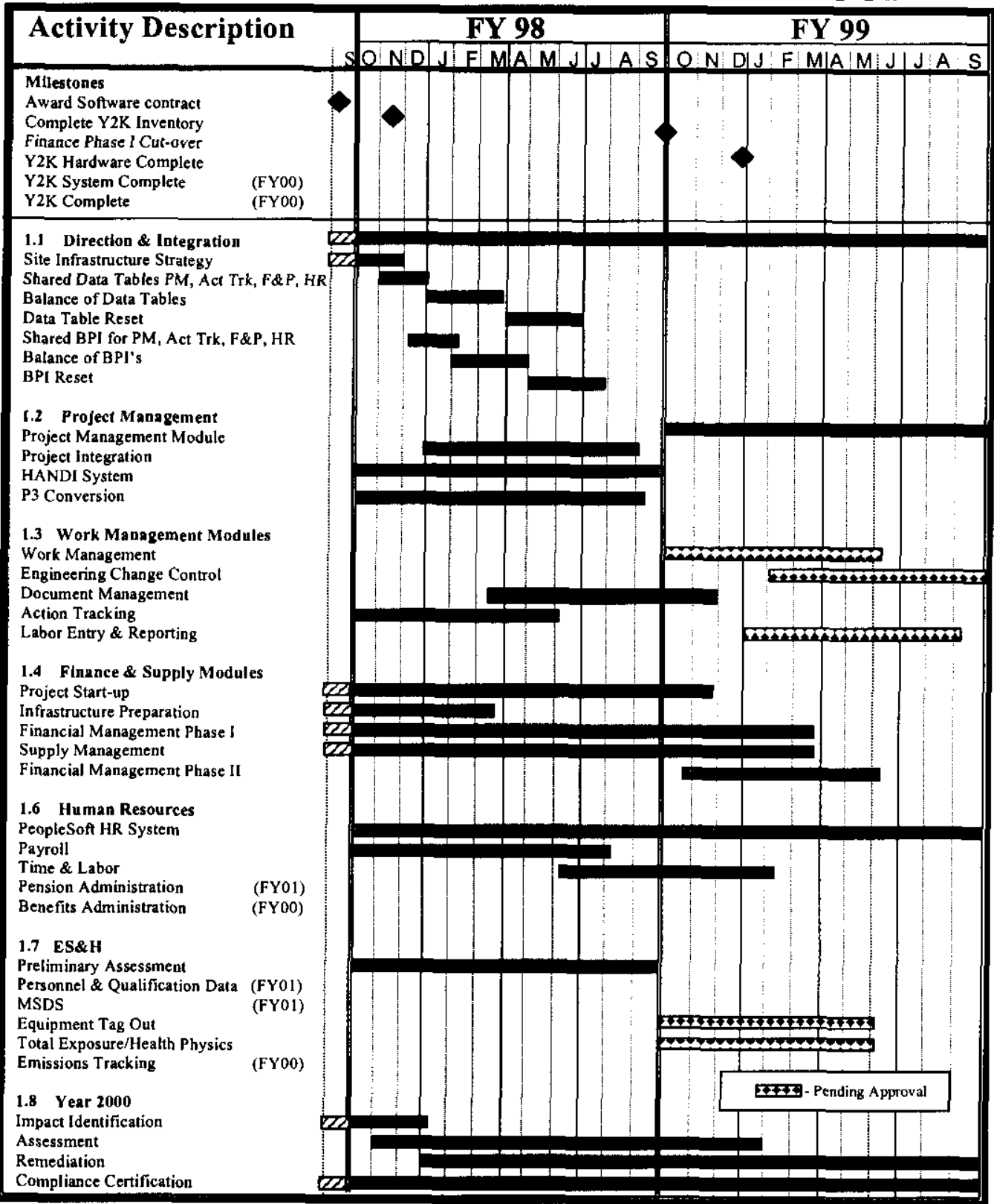

\section{ESTIMATED COST}


Project Name: HANDI 2000

Document Number: HNF-1743
Publication Date: November 5, 1997

Page: 25 of 63

Revision: 1

Cost represented in this table are estimates from ERP white paper updated with 1997 estimated accruals, FY 1998 HANDI 2000 Annual Work Plan and subproject project execution plans (PEP).

Table: HANDI 2000 Project Estimated Cost by WBS Element (\$1M)

\begin{tabular}{|c|c|c|c|c|c|c|c|}
\hline \multicolumn{2}{|c|}{\begin{tabular}{|l|l}
$\mid$ \\
Yus
\end{tabular}} & 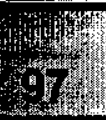 & FY 98 & FY99 & FYoo & FYONR & Total \\
\hline 1.1 & Project Direction and Integration & $\$ 0.4$ & $\$ 1.2$ & $\$ 1.3$ & $\$ 1.3$ & $\$ 1.1$ & \\
\hline 1.2 & Project Management Modules & $\$ 0.0$ & $\$ 0.4$ & $\$ 1.1$ & $\$ 0.0$ & $\$ 0.0$ & \\
\hline 1.3 & Work Management Modules & $\$ 0.0$ & $\$ 0.8$ & $\$ 7.9$ & $\$ 2.6$ & $\$ 0.0$ & $\$ 11.2$ \\
\hline 1.4 & Finance \& Supply Management $\left(^{*}\right)$ & $\$ 3.4$ & $\$ 11.5$ & $\$ 0.7$ & $\$ 0.0$ & $\$ 0.0$ & $\$ 12.2$ \\
\hline 1.6 & Human Resources Modules & $\$ 0.0$ & $\$ 1.2$ & $\$ 0.4$ & $\$ 0.3$ & $\$ 2.1$ & $\$ 4.0$ \\
\hline 1.7 & ES\&H Modules & $\$ 0.0$ & $\$ 0.2$ & $\$ 2.2$ & $\$ 1.5$ & $\$ 2.7$ & $\$ 6.7$ \\
\hline 1.8 & Year 2000 (FDH Only) & $\$ 1.2$ & $\$ 4.7$ & $\$ 1.7$ & $\$ 1.0$ & $\$ 0.0$ & $\$ 8.7$ \\
\hline Total H & ANDI-2000 Estimates & $\$ 5.0$ & $\$ 19.9$ & $\$ 15.3$ & $\$ 6.7$ & $\$ 5.9$ & $\$ 49.5$ \\
\hline & Year $2000($ Non-FDH $)\left({ }^{* \star}\right)$ & $\$ 0.5$ & $\$ 5.1$ & $\$ 1.5$ & $\$ 0.7$ & $\$ 0.0$ & $\$ 7.8$ \\
\hline \multicolumn{8}{|c|}{ 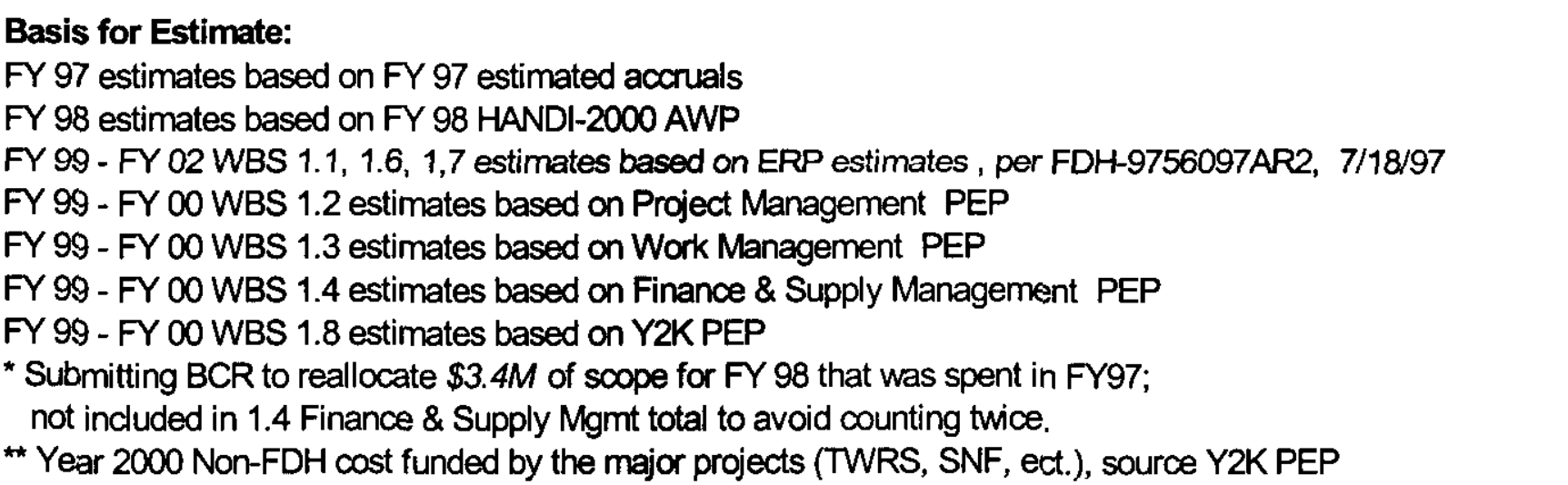 } \\
\hline
\end{tabular}


Project Name: HANDI 2000

Document Number: HNF-1743
Publication Date: November 5, 1997

Page: 26 of 63

Revision: 1

\section{RISK MITIGATION PLAN}

\section{Risk Management}

Risk Management is the process of identifying areas of risk that can negatively impact a project and taking the necessary mitigation actions to reduce the risk to ensure a successful project.

The following identifies the risks to be mitigated for the HANDI 2000 Project:

\begin{tabular}{|c|c|c|}
\hline \multicolumn{3}{|c|}{ Risk Management Table } \\
\hline Type & Risk & Mitigation \\
\hline Technical & $\begin{array}{l}\text { Legacy data will initially still be on the mainframe } \\
\text { and must be accessible for some time - possibly } \\
\text { years }\end{array}$ & $\begin{array}{l}\text { Study the three major alternatives: } \\
\text { - Mapping and migrating the old data to a } \\
\text { new, but smaller servers } \\
\text { - Out-source the storage and mainframe } \\
\text { services, without maintaining full legacy } \\
\text { systems } \\
\text { - Archive data in readable format with } \\
\text { access tool for ready access }\end{array}$ \\
\hline Technical & $\begin{array}{l}\text { Incomplete integration - not all of the interfaces } \\
\text { between Indus Passport and PeopleSoft modules } \\
\text { have been written and tested by the vendor }\end{array}$ & $\begin{array}{l}\text { Vendor contractually warranties } \\
\text { integration - have the vendors committed to } \\
\text { demonstration integration for payment } \\
\text { - Phase approach will allow evaluation of } \\
\text { technology and performance by module }\end{array}$ \\
\hline Technical & $\begin{array}{l}\text { PeopleSoft and Indus personnel both are said to be } \\
\text { somewhat "stove piped in their areas of experience } \\
\text { and expertise }\end{array}$ & $\begin{array}{l}\text { Required vendor personnel experience in } \\
\text { multiple modules }\end{array}$ \\
\hline
\end{tabular}




\begin{tabular}{|c|c|c|}
\hline \multicolumn{3}{|c|}{ Risk Management Table } \\
\hline Type & Risk & Mitigation \\
\hline Technical & $\begin{array}{l}\text { Inadequate desktops - PHMC Teams current desktop } \\
\text { PC's are not powerful enough to run the new } \\
\text { systems }\end{array}$ & $\begin{array}{l}\text { A site plan to upgrade desktops hardware } \\
\text { and software is underway, but separate } \\
\text { funding status is uncertain, upgrading must be } \\
\text { integrated with plans for all proposed new } \\
\text { software } \\
\text { - Overall site architecture to be developed } \\
\text { by } 12 / 97 \\
\text { - Align desktop allocation to phased } \\
\text { implementation ensuring resources are } \\
\text { available to those who need them first }\end{array}$ \\
\hline Technical & $\begin{array}{l}\text { Package experience - Only one site has similar } \\
\text { software (i.e., Indus/PeopleSoft) combination up and } \\
\text { running. (Several more will have before Hanford } \\
\text { completes implementation) }\end{array}$ & $\begin{array}{l}\text { Partner with other locations, including other } \\
\text { first tier contractors at Hanford, in support } \\
\text { groups to share experiences in } \\
\text { implementation }\end{array}$ \\
\hline Technical & $\begin{array}{l}\text { As each step in the migration process is executed, } \\
\text { one or several legacy systems will be rolled into } \\
\text { transition status and data interfaces with the legacy } \\
\text { systems will be upgraded to the new scenario. } \\
\text { Parallel processes, production validation, and the } \\
\text { changing workloads for hardware, software, and } \\
\text { people will have to be conducted efficiently and } \\
\text { effectively so business continuity and module/data } \\
\text { integrity can be maintained. }\end{array}$ & $\begin{array}{l}\text { Detailed planning aligned with business } \\
\text { process improvement TO-BE results, to } \\
\text { minimize process disruptions. Use of a } \\
\text { knowledge base that identifies system and } \\
\text { data interactions and their relationships to } \\
\text { business processes. }\end{array}$ \\
\hline Technical & $\begin{array}{l}\text { Customizing control - customizing the baseline ERP } \\
\text { software beyond user options, will defeat the } \\
\text { anticipated cost savings and delay the } \\
\text { implementation }\end{array}$ & $\begin{array}{l}\text { - Implement a change control board } \\
\text { - Resist the temptation by redesigning } \\
\text { process } \\
\text { - Identify strong executive sponsorship }\end{array}$ \\
\hline Technical & $\begin{array}{l}\text { Decisions made early in the implementation of ERP } \\
\text { software, for example, facility naming conventions } \\
\text { established in the prototype Deficiency Tracking } \\
\text { System, will dictate implementations of later } \\
\text { modules. The owners and stakeholders of facility } \\
\text { data risk losing control of their information and } \\
\text { subsequent control of key processes. }\end{array}$ & $\begin{array}{l}\text { Stakeholder identification and coordination } \\
\text { prior to establishing shared data in the ERP } \\
\text { software database. }\end{array}$ \\
\hline
\end{tabular}


Project Name: HANDI 2000

Document Number: HNF-1743
Publication Date: November 5, 1997

Page: 28 of 63

Revision: 1

\begin{tabular}{|c|c|c|}
\hline \multicolumn{3}{|c|}{ Risk Management Table } \\
\hline Type & Risk & Mitigation \\
\hline Technical & $\begin{array}{l}\text { More than one system and data set will be replaced } \\
\text { by a single module and/or data set. In the ERP } \\
\text { software environment, these processes and } \\
\text { organizations will share module and data definitions. } \\
\text { There is a risk : } \\
\text { - Individual needs being lost in the defining the } \\
\text { new AS-IS process. } \\
\text { - Organizations will continue their legacy } \\
\text { information systems, with associated maintenance } \\
\text { and operations costs and defeating the premise that } \\
\text { economies can be achieved with ERP software } \\
\text { implementation of one process, one system. } \\
\text { - Centralization of the process and meeting the } \\
\text { needs of all constituents can lead to overkill } \\
\text { solutions for processes and organizations simply } \\
\text { tracking their specialized actions. }\end{array}$ & $\begin{array}{l}\text { Business process improvement with } \\
\text { participation and buy-in by affected } \\
\text { stakeholders, down to the level of identifying } \\
\text { controlled data items and process elements } \\
\text { with an open-ended implementation to meet } \\
\text { process-specific needs. }\end{array}$ \\
\hline Technical & $\begin{array}{l}\text { Other Hanford Contractors serve as process users, } \\
\text { data providers, and operators, under contractual } \\
\text { arrangements with the PHMC Team and other } \\
\text { Hanford organizations. Their roles with respect to } \\
\text { the ERP software are currently undefined, except } \\
\text { where they are funded for specific tasks. Data } \\
\text { scopes and process responsibilities should be defined } \\
\text { in terms of the PHMC responsibilities, yet useful } \\
\text { information can be lost when scoping down the } \\
\text { information included or the processes supported by } \\
\text { the ERP software. }\end{array}$ & $\begin{array}{l}\text { Define boundaries of the data managed } \\
\text { centrally by the ERP software. } \\
\text { Devise a mutual interest scenario that } \\
\text { supports usage by more than PHMC Team } \\
\text { members and define data stewardship, } \\
\text { funding, and process management tools to } \\
\text { allow sharing the system. }\end{array}$ \\
\hline Financial & Scope changes resulting in escalating cost & $\begin{array}{l}\text { Formal change control board will control } \\
\text { changes in scope and funding }\end{array}$ \\
\hline Financial & $\begin{array}{l}\text { HANDI } 2000 \text { funding priorities will change as } \\
\text { annual PHMC budget priorities change }\end{array}$ & $\begin{array}{l}\text { Phased approach is based upon funds } \\
\text { available and deliverables by year, and at the } \\
\text { subproject level (business area) }\end{array}$ \\
\hline
\end{tabular}


Revision: 1

\begin{tabular}{|c|c|c|}
\hline \multicolumn{3}{|c|}{ Risk Management Table } \\
\hline Type & Risk & Mitigation \\
\hline Financial & $\begin{array}{l}\text { HANDI } 2000 \text { is close to the margin on the } \\
\text { Integrated Priority List (IPL) and an easy target for } \\
\text { funding cuts }\end{array}$ & $\begin{array}{l}\text { Place higher priority to HANDI } 2000 \\
\text { Project on the IPL } \\
\text { Focus on business areas that will give an } \\
\text { early and high return on investment } \\
\text { Break into business area components to } \\
\text { reduce risk total risk }\end{array}$ \\
\hline Personnel & $\begin{array}{l}\text { Pain of culture change too high, creating resistance, } \\
\text { schedule delays, and cost overrun }\end{array}$ & $\begin{array}{l}\text { Strengthen DOE/PHMC Team } \\
\text { management alignment and support } \\
\text { - Communicate the benefits of the new } \\
\text { system to the individual users }\end{array}$ \\
\hline Personnel & $\begin{array}{l}\text { Jobs will be eliminated as legacy systems are retired } \\
\text { and processes are improved, if users relate the } \\
\text { technology changes with job jeopardy this will slow } \\
\text { acceptance and full implementation }\end{array}$ & $\begin{array}{l}\text { Retrain or re-deploy personnel into } \\
\text { mission essential projects } \\
\text { - Personnel who work on implementation } \\
\text { will gain new skills }\end{array}$ \\
\hline Personnel & $\begin{array}{l}\text { LMSI personnel familiar with PeopleSoft and } \\
\text { INDUS is a potentially limiting resource }\end{array}$ & $\begin{array}{l}\text { Begin now searching for more talent - } \\
\text { either as employees or contract personnel. } \\
\text { Develop a package or individual } \\
\text { incentive for those who stay through } \\
\text { completion } \\
\text { INDUS will provide local support } \\
\text { - Leverage the partnership between Indus } \\
\text { and PeopleSoft }\end{array}$ \\
\hline
\end{tabular}


Project Name: HANDI 2000

Document Number: HNF-1743
Publication Date: November 5, 1997

Page: 30 of 63

Revision: 1

\section{COMMUNICATION PLAN}

\section{Overview}

The following outlines the communication activities proposed for the project that will integrate the PHMC Team business processes through business process improvement and through implementing a business wide integrated data system, HANDI 2000. This plan covers the overall project. Individual subprojects may draft their own communications plans to supplement and complement this plan. HANDI 2000 is an extensive redesign of major business processes at Hanford beginning in August 1997 and continuing to full implementation in about four years.

\section{Audience(s)}

- PHMC Team companies employees

- Hanford Site employees

- DOE-RL officials

- Other interested parties

\section{Strategy}

The overall strategy is to provide all interested audiences with significant information to

- Help them understand the rationale for the HANDI 2000 implementation

- Keep them informed of progress

- Engage affected parties involvement

- Ease the transition to new work processes and tools for Hanford site employees

\section{Philosophy}

\section{COMMUNICATION IS THE GREASE, NOT THE PRODUCT}

Project Mangers need to manage their projects. Beyond providing status-reporting presentations to project sponsors, they should not spend their time doing presentations. A well-informed communication person can perform this activity.

CREATE ONCE AND RE-USE (Outlined standards)

Create presentations using a standard master with only HANDI 2000 logo and re-use for specific needs rather than re-develop. 
Project Name: HANDI 2000

Document Number: HNF-1743
Publication Date: November 5, 1997

Page: 31 of 63

Revision: 1

Communication must tell the truth rather than "sugar coat" the message. This relates primarily to problems encountered during implementation and reductions in-force related to project.

\section{ACTIONS SPEAK LOUDEST}

Face-to-face communication is generally the most effective way to share information. It is important to realize that all interactions, including informal ones are communication opportunities

\section{KEEP THE TEAM ON THE SAME PAGE}

Sharing progress, problems, and successes amongst team members helps develop consistency in the informal messages picked up by others. This consistency helps increase trust.

\section{EVERYONE IS A COMMUNICATOR}

To those not part of the implementation every person on the implementation team is seen to have responsibility to provide information.

\section{Message (s)}

The general messages are:

- HANDI 2000 description: The HANDI 2000 system is a comprehensive set of functional applications integrated through a common database and containing core information needed to run a company.

- Drivers: Year 2000 problems / Over 600 systems / Move from inefficient and complex work processes to commercial standards / Obsolete legacy technology / Reduce IRM costs / Accelerate cleanup

- Implementation will require a significant effort from employees and will not be without impact to our ongoing operations.

- Employees will be updated regularly about project activities and "What's in it for me".

- Who, What, Where, When, Why, and How 
Project Name: HANDI 2000

Document Number: HNF-1743

\section{Background}

HANDI 2000 will be implemented in phases as the PHMC Team business processes undergo business process improvement redesign. Human Resources is already on a HANDI 2000 compliant system. Action Tracking, Financial, and Supply Management will be the first processes to be redesigned and implemented by the HANDI 2000 project.

\section{Sensitivities}

- Integrating business processes with HANDI 2000 is a difficult concept to visualize and its very complexity will necessitate crisp, concise communications.

- Any change can be stressful for employees and result in their "going to ground" and resisting implementation.

- Management of expectations will be important, both for the client and for employees (don't want to overstate the capabilities of HANDI 2000).

- It will be important to develop a shared vision at the senior management level if continuous support is expected

- Implementation will be long and difficult; many will lose interest

- HANDI 2000 will reduce costs therefore some employees will be displaced from their current functions. They should be treated with compassion and respect. They should be given every opportunity to be retrained and relocated.

\section{Media}

- Face to Face (2-Way)

- Brochure

- E-mail

- Presentations (1-Way)

- Events

- Posters/Charts

- Newsletter

- Letter/Memo

- Activities

- Web page 
Project Name: HANDI 2000

Document Number: HNF-1743
Publication Date: November 5, 1997

Page: 33 of 63

Revision: 1

\section{PROCUREMENT PLAN}

The HANDI 2000 Project will use and has used commercial procurement practices to ensure the timely completion of schedule.

The overall approach is to utilize a limited competitive procurement for a full Enterprise Resource Planning solution from a single integrating vendor.

A short list was developed based on recent competitive procurement at other DOE sites.

Vendors on that short list had demonstrated a technical capability to meet DOE requirements at competitive prices. They were invited to put together teams to provide us with a total solution.

Acquisition was divided into two phases:

Phase 1: Procure the software and integration products necessary to address our needs. Consisted of a base capability for finance and supply with options for Work management and ES\&H capabilities. Vendor contracted to deliver and install the software. Also procured limited vendor technical support to assess our environment, recommends an implementation path forward and supports technical planning.

Phase 2: Procure the services of a third party to fully implement the procured solution in multiple solution sets. The initial solution set consists of the financial system and a new supply-chain process. Alternatives to be considered include utilizing the selected vendor, contracting through LMSI, utilizing the services of a different existing Hanford subcontractor and obtaining the services of an outside consulting firm other than the selected vendor.

The vendor selected in phase 1 will be responsible for providing an integrated set of software capable of meeting the functional requirements set forth in the procurement.

The vendor selected in phase 2 will be responsible for implementing the purchased solution, working in conjunction with PHMC personnel. The scope of work includes facilitating development of work processes by PHMC personnel to utilize the new capabilities, assisting PHMC personnel in establishing software table structures and loading data from existing systems, and directing the efforts of all subcontracted activities.

Due to the urgency of $\mathrm{Y} 2 \mathrm{~K}$ efforts, and a general lack of a competitive resource base, the procurement of $\mathrm{Y} 2 \mathrm{~K}$ tools and equipment will primarily be sole-sourced. 
Project Name: HANDI 2000

Document Number: HNF-1743
Publication Date: November 5, 1997

Page: 34 of 63

Revision: 1

\section{DATA MANAGEMENT}

The HANDI 2000 Data Management activity supports effective installation and use of ERP software in the areas of data definitions, information system migration to the ERP software, data migration from legacy information systems, active interfaces with external information systems, and ongoing data stewardship. Policy, procedural, and information technology techniques will be used to achieve specified data requirements. Data management is conducted under the Configuration Management Plan.

\section{Scope and Deliverables}

Data management activities will deliver, or actively support the delivery of, methods for

- Capturing and interpreting business data requirements.

- Coordinating the development of common ERP software-based data definitions and standards among multiple organizations, processes, and information systems that create or use the data.

- Migrating existing data from multiple sources in accordance with data upload specifications.

- Responsible data stewardship by creators and users of data such that data quality is known and maintained at the level needed.

- Managing data configuration, including definition, quality, traceability, relationships, timing, accessibility, and formats to meet the needs of affected organizations, products, and external interfaces.

\section{Strategy}

Data management will be conducted as a component of the HANDI 2000 Configuration Management Plan.

Data standards to meet stakeholder and ERP software requirements will be implemented across the PHMC Team using Chief Information Officer (CIO) procedures. HANDI 2000 requests for specific policy or procedure changes will be brought to the Site Data Management Core Group, under the CIO, for evaluation and implementation. 
Project Name: HANDI 2000

Document Number: HNF-1743
Publication Date: November 5, 1997

Page: 35 of 63

Revision: 1

Hanford data management principles will be followed:

- Manage data and information from a business perspective

- Collect data only once.

- Establish and enforce data standards

- Share data, based on need.

- Control and protect data and information.

- Actively pursue information quality.

Data management processes will be standardized across the project and consistent with PHMC Team processes. HANDI 2000 standards based on Indus methods will be adopted by each business process module.

The Indus Business Process Improvement (BPI) process will surface data needs and conflicts for the ERP software products, thus identifying areas where data needs management outside a single business process.

Integration and business unit representatives will team to address data needs, processes, and standards. Representatives of the integration team will attend all product business process improvement (TO-BE) sessions to ensure data standards and interface requirements are met.

Data management methodologies and tools that are not specific to ERP software will be established in the IRM change management process under the authority of the IRM Change Board. 
Project Name: HANDI 2000

Document Number: HNF-1743
Publication Date: November 5, 1997

Page: 36 of 63

Revision: 1

\section{CONFIGURATION MANAGEMENT}

\section{Introduction}

HANDI 2000 project consists of several major subprojects running in a combination of parallel and sequential implementations. The ERP software purchases from Indus and PeopleSoft each runs on top of its own physical Oracle database. These two physical databases are crossreferenced and synchronized through an integration product supplied by Indus. The project planning software purchased from Primavera runs on top of a proprietary database. This database will also be cross-referenced and synchronized through in integration product being developed for us by Indus. This vendor-supplied integration will provide us with a single logical database where data is shared by all applications.

Because data is completely shared and processes are typically intertwined, effective configuration management is crucial for successful implementation.

\section{Scope}

All new proposed IRM applications that could impact the HAND-2000 Projects and any modifications to the baseline software. All HANDI 2000 subprojects are required to comply with the configuration management process.

\section{Stewardship}

Because information will be used by many different business functions, the concept of unilateral ownership of data is counterproductive. Many different constituencies will need to be consulted in establishing data structures, contents, and controls. However, with a data system of this complexity decision by committee is unproductive.

Each data element and business function will have a steward. A steward is expected to manage his assigned elements in the best interest of all stakeholders by being aware of their needs and implementing decisions that best support the overall business needs. Each data element and business function will be documented along with one steward and one or more stakeholders.

\section{Process}

The project configuration control function will maintain a complete list of data elements, business processes, assigned stewards and stakeholders

All changes, additions, or deletions to the production HANDI 2000 system will require the authorization of the assigned steward. The Project Configuration Control function will oversee 
Project Name: HANDI 2000

Document Number: HNF-1743
Publication Date: November 5, 1997

Page: 37 of 63

Revision: 1

the effectiveness of overall integration and control. It will reconcile discrepancies or shortcomings as necessary

Change Control for HANDI 2000 will use existing PHMC methods and procedures, with one major exception: All proposed changes to the baseline ERP software will be disposition by the HANDI 2000 Change Control Board. The HANDI 2000 Change Control Board will comprise the following members:

$\begin{array}{ll}\text { HANDI 2000 Project Director, Chair } & \text { Fumio Otsu } \\ \text { Project Control Director } & \text { Ed Penn } \\ \text { Chief Information Officer } & \text { Harry Sterling } \\ \text { DOE-RL Chief Financial Officer } & \text { Alice Murphy } \\ \text { Director of Business Process Alignment } & \text { Marnie Ross }\end{array}$

This board does not replace existing boards but is in addition thereto.

\section{Change Management}

This section describes a project-level change management process for HANDI 2000, which is described consistent with change control as presented in the M\&I Plan.

Section 6.3 "Configuration Management" of the M\&I Plan states:

"Baseline Change Boards control Changes to the integrated baseline at three different levels: the project level, the Site level, and the RL level. Authority limits will be established at the project and Site levels in consultation with RL."

The project-level change process established to manage the HANDI 2000 integrated baseline operates in accordance with the Configuration Management Plan (FDH 1996).

The HANDI 2000 Change Management process is owned and managed by the HANDI 2000 Project Director through the HANDI 2000 Change Control Board. The process works in conjunction with the PHMC Change Control Board for baseline change requests (BCR) against Annual Work Plans (AWPs), including associated modifications to Performance Agreement (PAs). 
Project Name: HANDI 2000

Document Number: HNF-1743
Publication Date: November 5, 1997

Page: 38 of 63

Revision: 1

HANDI 2000 Change Control Board Process

\begin{tabular}{|c|c|c|c|c|}
\hline & $\begin{array}{l}\text { Hanford Site } \\
\text { Baseline Change }\end{array}$ & $\begin{array}{l}\text { Project Baseline } \\
\text { Change Request }\end{array}$ & $\begin{array}{l}\text { ERP software } \\
\text { baseline change }\end{array}$ & $\begin{array}{l}\text { IRM system HANDI } \\
2000 \text { integration }\end{array}$ \\
\hline $\begin{array}{l}\text { PHMC Change } \\
\text { Control Board }\end{array}$ & \multirow{3}{*}{$\begin{array}{l}\text { For scope and cost } \\
\text { not budgeted in the } \\
\text { HANDI } 2000 \text { AWP } \\
\text { (CIO will evaluate } \\
\text { for IRM Change } \\
\text { Board involvement) }\end{array}$} & \multirow{2}{*}{$\begin{array}{l}\text { For scope and costs } \\
\text { changes funded by } \\
\text { the HANDI } 2000 \\
\text { AWP }\end{array}$} & Hatum & \multirow{4}{*}{$\begin{array}{l}\text { Systems that have a } \\
\text { potential to be } \\
\text { replaced or interface } \\
\text { with existing or } \\
\text { future planned ERP } \\
\text { software modules } \\
\text { will be screened for } \\
\text { applicability by the } \\
\text { IRM Change Board }\end{array}$} \\
\hline $\begin{array}{l}\text { HANDI } 2000 \text { Change } \\
\text { Control Board }\end{array}$ & & & $\begin{array}{l}\text { ERP software } \\
\text { customization }\end{array}$ & \\
\hline IRM Change Board & & & & \\
\hline IRM Service Provider & \begin{tabular}{|c|c|} 
\\
4
\end{tabular} & " & \begin{tabular}{|c|c|} 
\\
\\
\end{tabular} & \\
\hline
\end{tabular}

\section{Baseline Change Requests}

The HANDI 2000 Baseline has technical, schedule, and cost components. Changes in cost, schedule, and technical work scope are the basis for a BCR. These change requests address changes within the annual work plan. When a BCR exceeds the authorized threshold, it is approved by the HANDI 2000 Change Control Board and forwarded to the PHMC Team Site Baseline Change Control Board. The Chief Information Officer will evaluate all changes approved by the HANDI 2000 change board whether they should be submitted through the IRM change management process

\section{HANDI 2000 ERP Software System Baseline Changes}

All proposed changes to the baseline software will be addressed to the HANDI 2000 Change Control Board. Any HANDI 2000 ERP software system that requires any programming changes to the software that would have an impact on the functionality of other integrated software modules or implementation of new customized revisions must be approved by the HANDI 2000 Change Control Board. Prior to presenting changes to the change board all requests will be reviewed by a HANDI 2000 Technical Review Board. That board will forward a recommendation to the HANDI 2000 Change Control Board that addresses the following points:

- Recommendation to approve/disapprove

- Assessment of technical merit of proposal

- Assessment of validity of cost, schedule, and risk projections

- Identification of possible alternatives outside the control of the project team

The overall flow of the software change process is shown in the following diagram. 
Project Name: HANDI 2000

Document Number: HNF-1743
Publication Date: November 5, 1997 Page: 39 of 63

Revision: 1

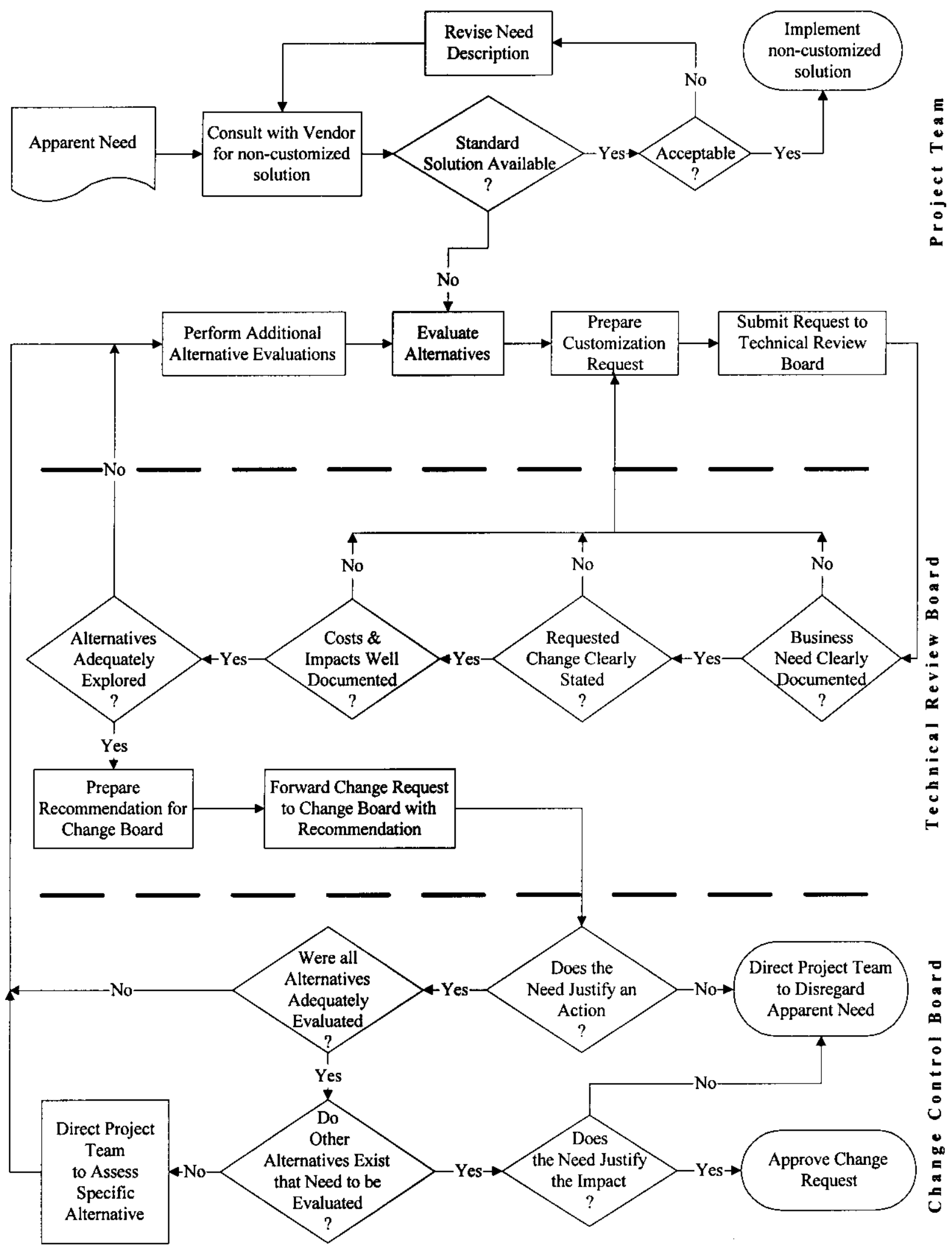

Change Request Process for Baseline Software 
Project Name: HANDI 2000

Document Number: HNF-1743
Publication Date: November 5, 1997

Page: 40 of 63

Revision: 1

\section{Problem Tracking and Resolution}

Central to effective configuration management is the identification, tracking and resolution of anomalies, commonly referred to as "bugs." Any observed system or process behaviors that are unexpected will be reported and tracked through a common process. Reported problems will be assessed to determine their nature and categorize them for action. Problems that relate to improper understanding or implementation of the product will be referred to the process design teams for correction. Problems that relate to our internal setup and operation of the software will be referred to the technical support organization for correction. Problems that relate to incorrect or inconsistent behavior of the software will be referred to Indus for resolution. During the implementation phase, Indus is the prime contractor for the total solution and all problems will be reported and resolved through them. As the implementation phase comes to completion, ongoing problem reporting and resolution processes will be established with the individual vendors: Indus, PeopleSoft and Primavera.

\section{System Integration}

Technologies that have a potential to be replaced or interface with HANDI 2000 ERP software must be evaluated for integration with HANDI 2000 ERP software. Initial screening of the IRM application for impacts on the HANDI 2000 Project will be conducted by the IRM Change Control Board, those that have a potential for impact will be forwarded to the HANDI 2000 Change Control Board for disposition. 


\section{SYSTEM INTEGRATION AND ADMINISTRATION PLAN}

\section{Introduction}

HANDI 2000 consists of eight distinct subprojects addressing major business functions. Each of the eight functional areas will be implemented as business cases are developed that demonstrate an appropriate need. Some functional areas, especially the downstream activities, may include additional scope as the business case is developed. For example, the Exposure subproject emphasizes the importance of tracking and managing radiation exposure for the PHMC scope of work, but there are additional environmental, safety and health functions such as material safety data sheets, emission tracking, etc. that may also be incorporated as the business case is developed. The eight functional areas are:

- Human Resources

- Program Planning

- Finance

- Action Tracking

- Supply Chain

- Work Management

- Document Management

- Exposure

The major integration issues to be managed are the overall coordination of the subproject activities, integration of the commercial products from three different vendors, and integration of external applications with the finished product.

\section{Program Logic}

The overall program logic is illustrated on the following eight logic diagrams. Interconnections and dependencies are noted as connection points on each diagram. The program logic allows executive and project management to see the interaction and dependencies of the various project activities. It forms the basis for making scope and performance tradeoffs, supports analysis of impacts resulting from schedule, budget or organizational issues, and serves as the upper-level planning tool from which subordinate schedules and budgets are structured.

All project planning, budgeting and performance measurement will trace back to the underlying program logic. If scope changes become necessary, they will be incorporated first into the program logic and then propagated into the detailed planning. 
Project Name: HANDI 2000

Document Number: HNF-1743
Publication Date: November 5, 1997

Page: 42 of 63

Revision: 1

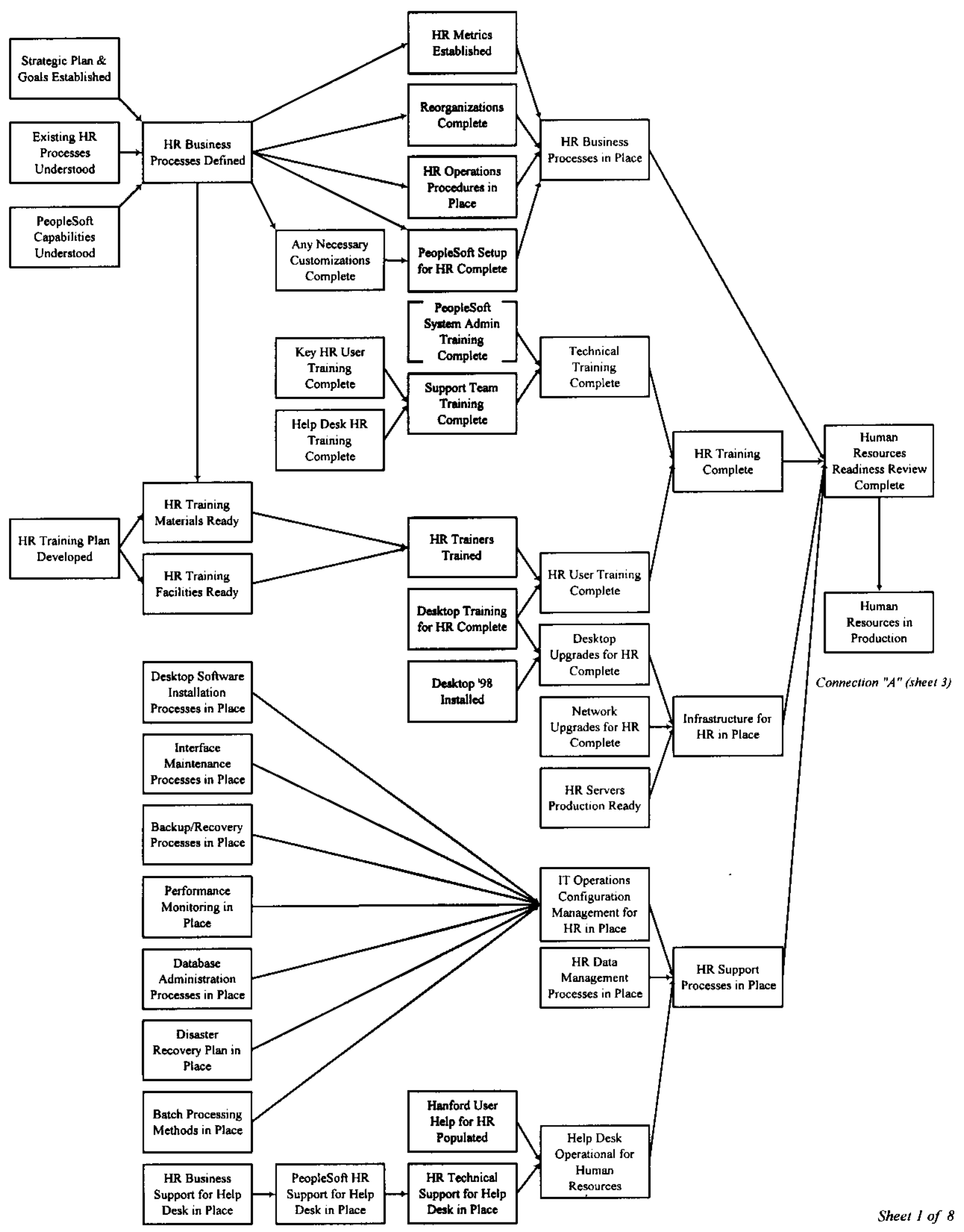

Human Resources Program Logic 
Project Name: HANDI 2000

Document Number: HNF-1743
Publication Date: November 5, 1997

Page: 43 of 63

Revision: 1

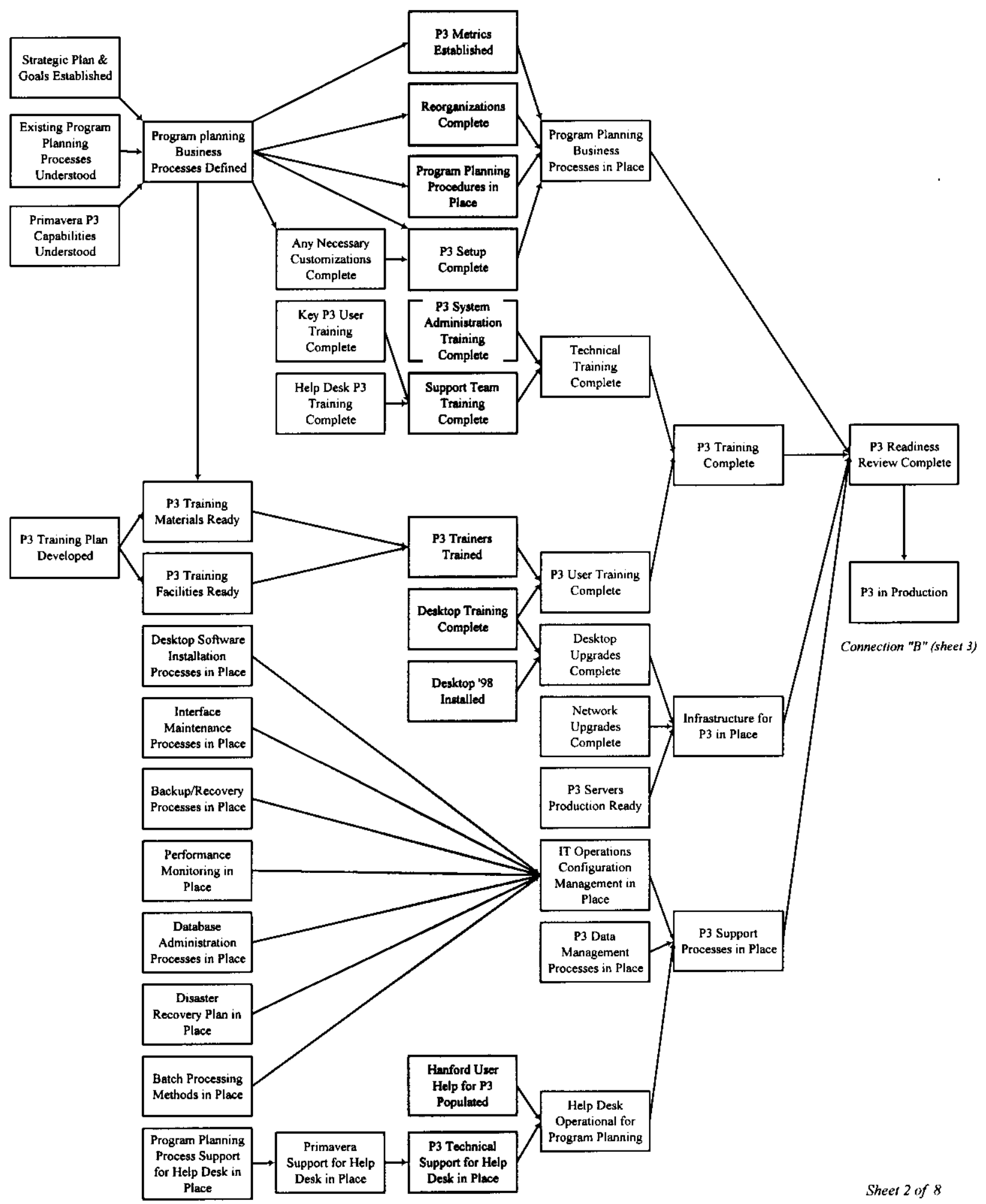

Primavera P3 Program Logic 
Project Name: HANDI 2000

Document Number: HNF-1743
Publication Date: November 5, 1997

Page: 44 of 63

Revision: 1

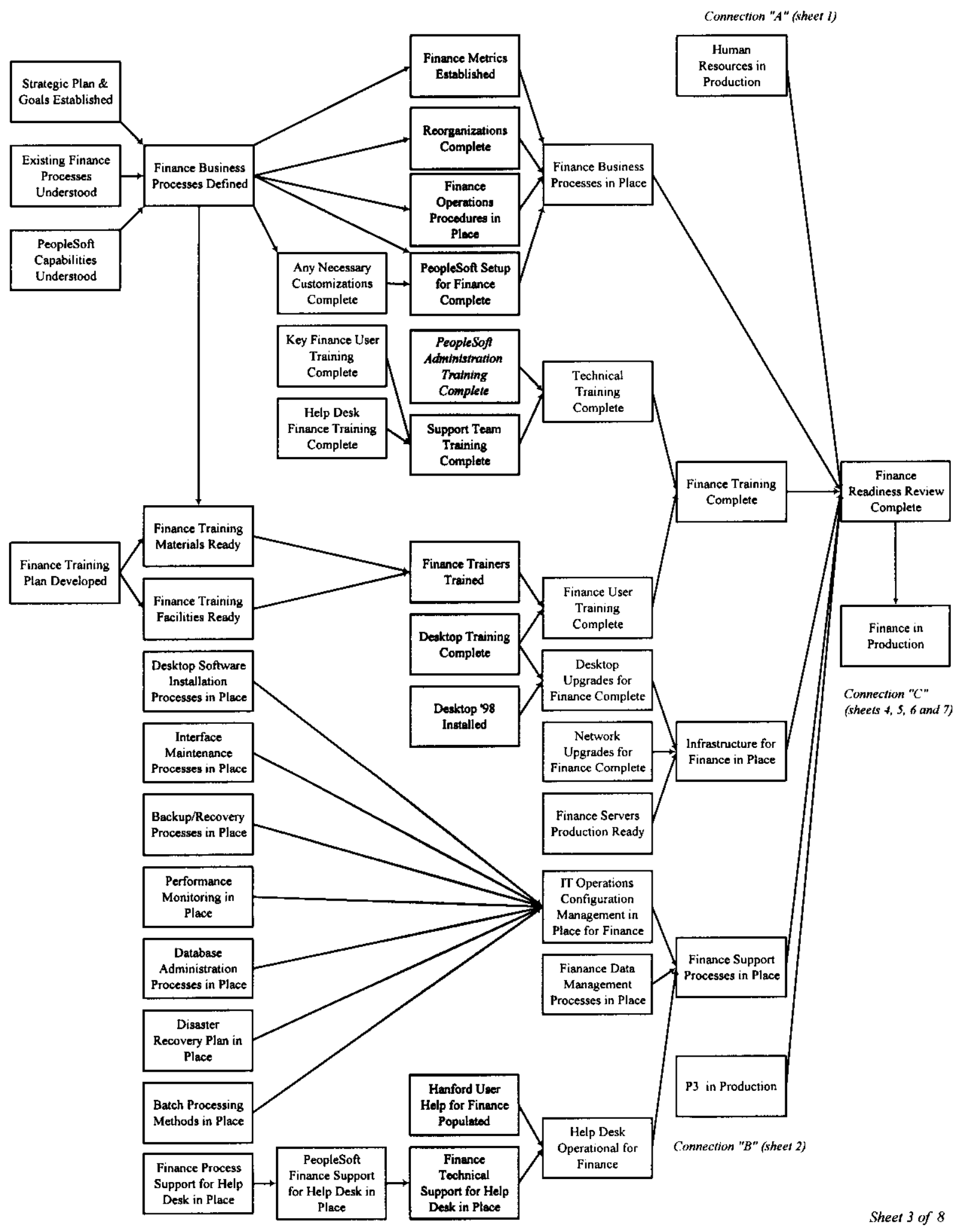

Finance Program Logic 
Project Name: HANDI 2000

Document Number: HNF-1743
Publication Date: November 5, 1997

Page: 45 of 63

Revision: 1

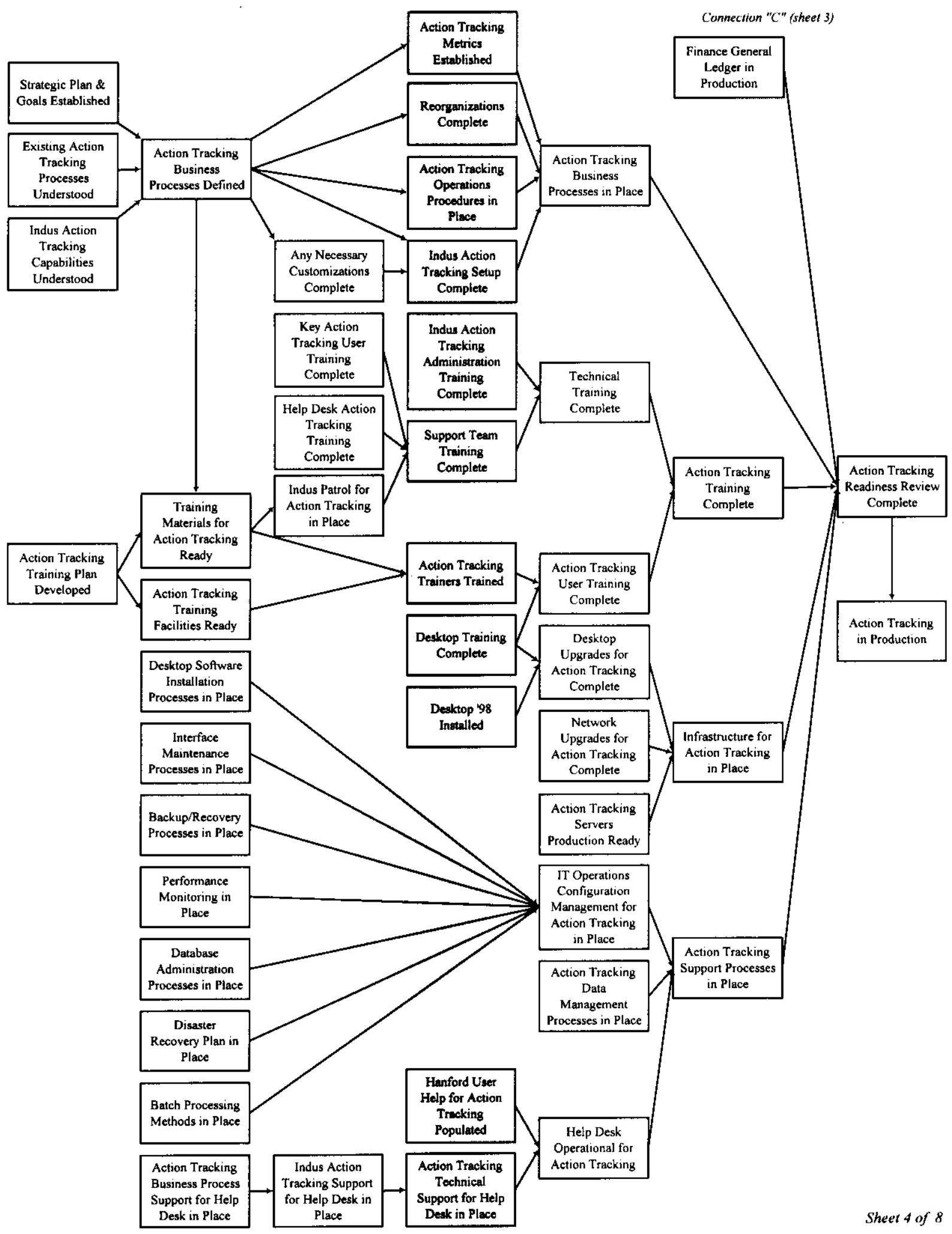

Action Tracking Program Logic 
Project Name: HANDI 2000

Document Number: HNF-1743
Publication Date: November 5, 1997

Page: 46 of 63

Revision: 1

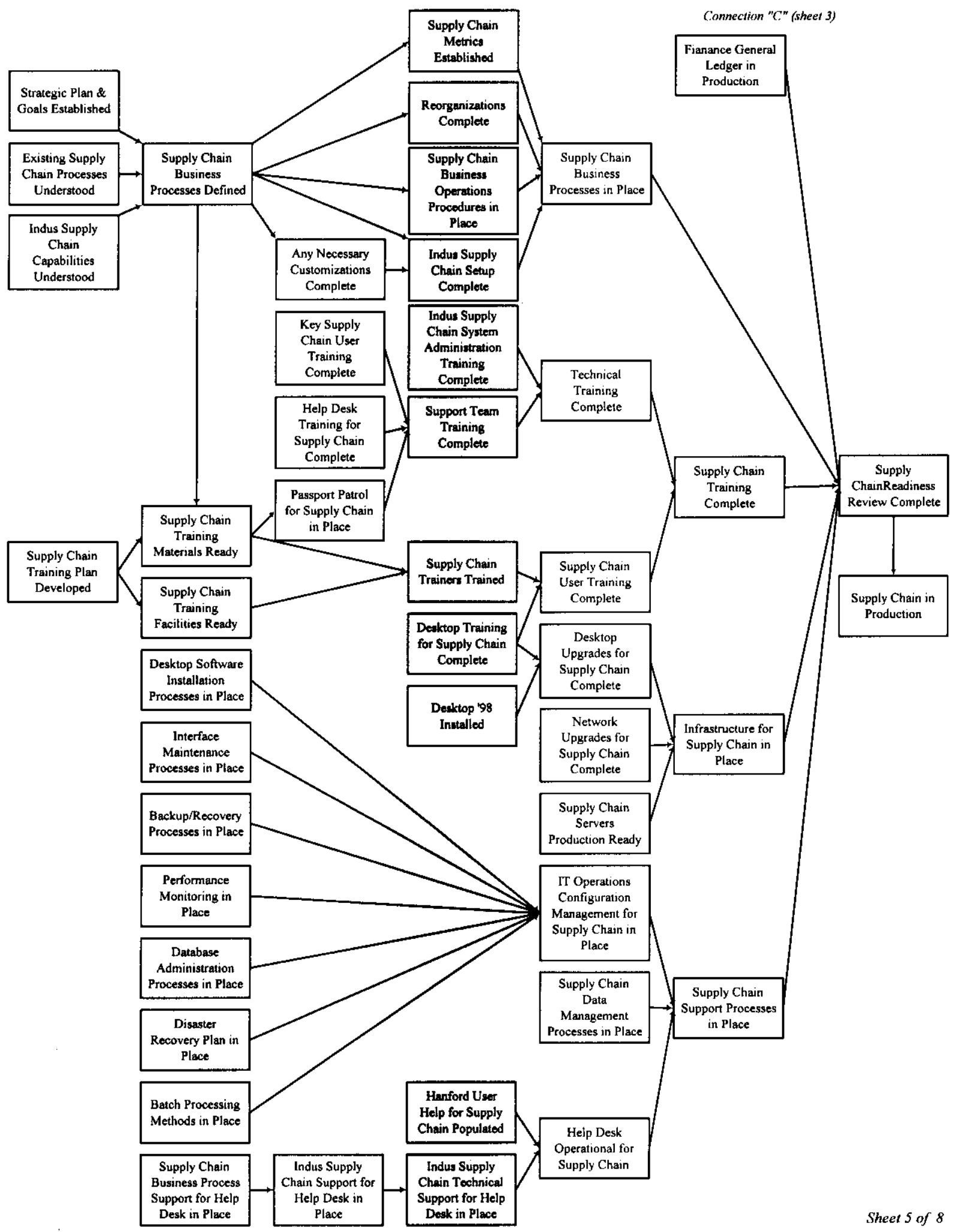

Supply Chain Program Logic 
Project Name: HANDI 2000

Document Number: HNF-1743
Publication Date: November 5, 1997

Page: 47 of 63

Revision: 1

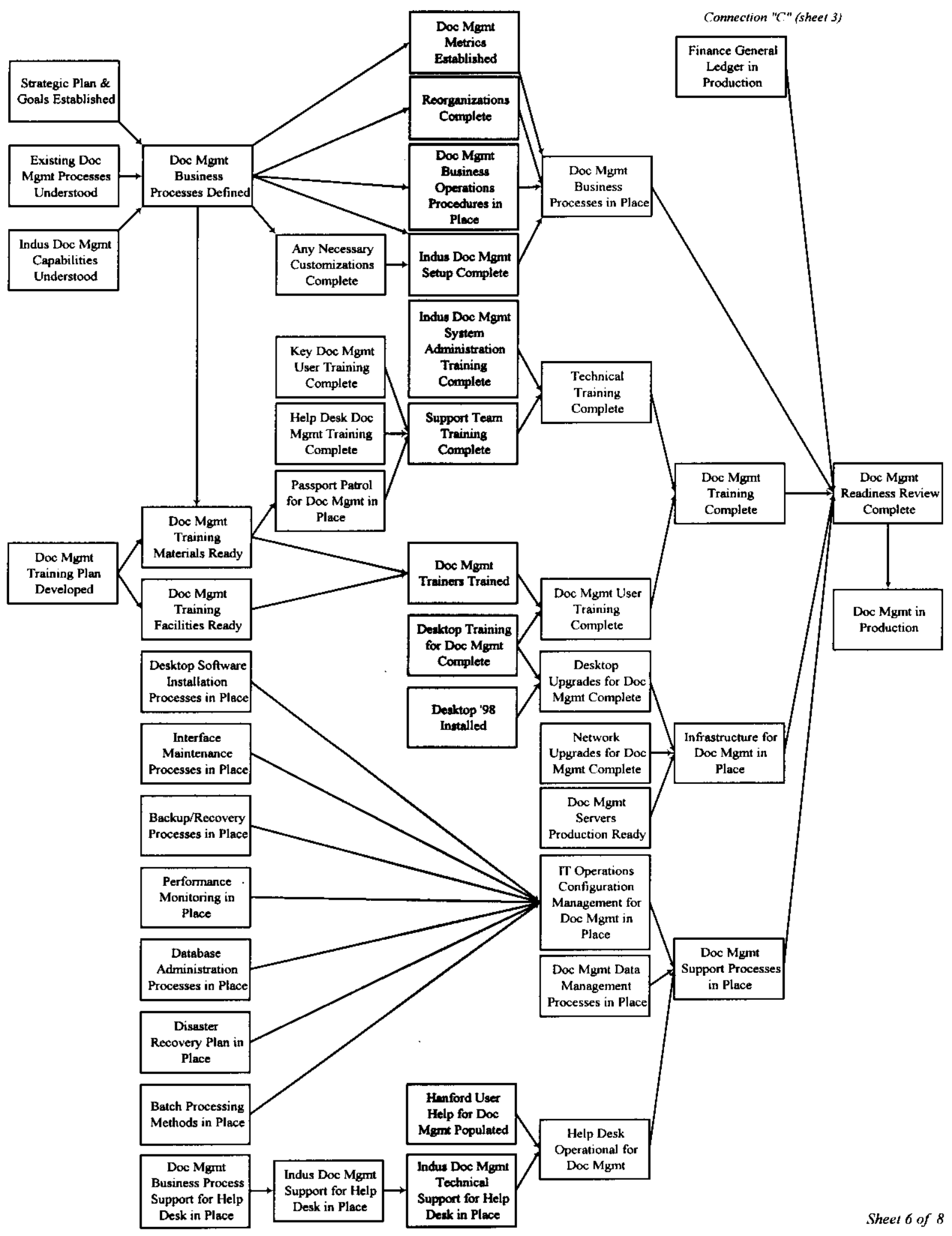

Document Management Program Logic 
Project Name: HANDI 2000

Document Number: HNF-1743
Publication Date: November 5, 1997

Page: 48 of 63

Revision: 1

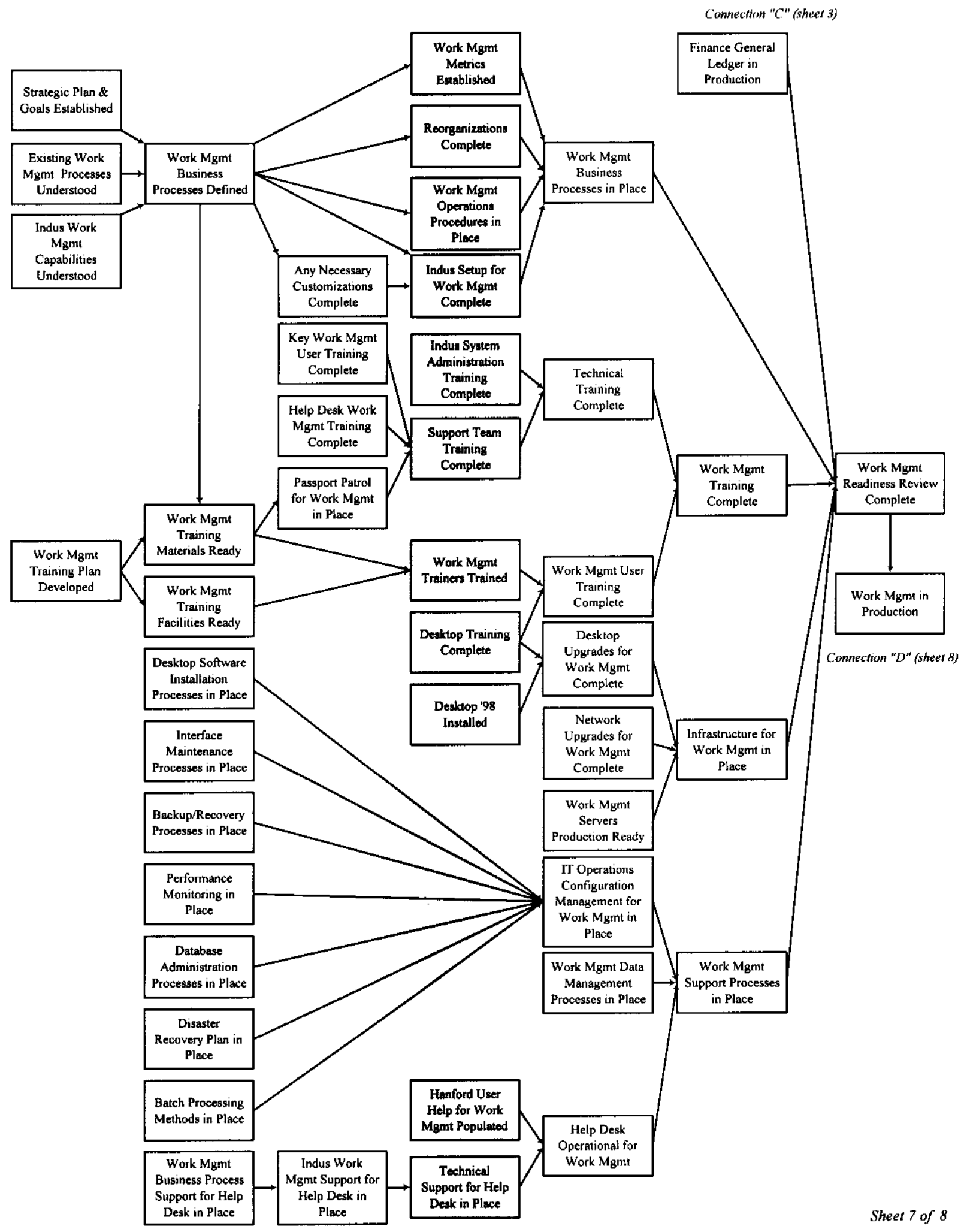

Work Mgmt Program Logic 
Project Name: HANDI 2000

Document Number: HNF-1743
Publication Date: November 5, 1997

Page: 49 of 63

Revision: 1

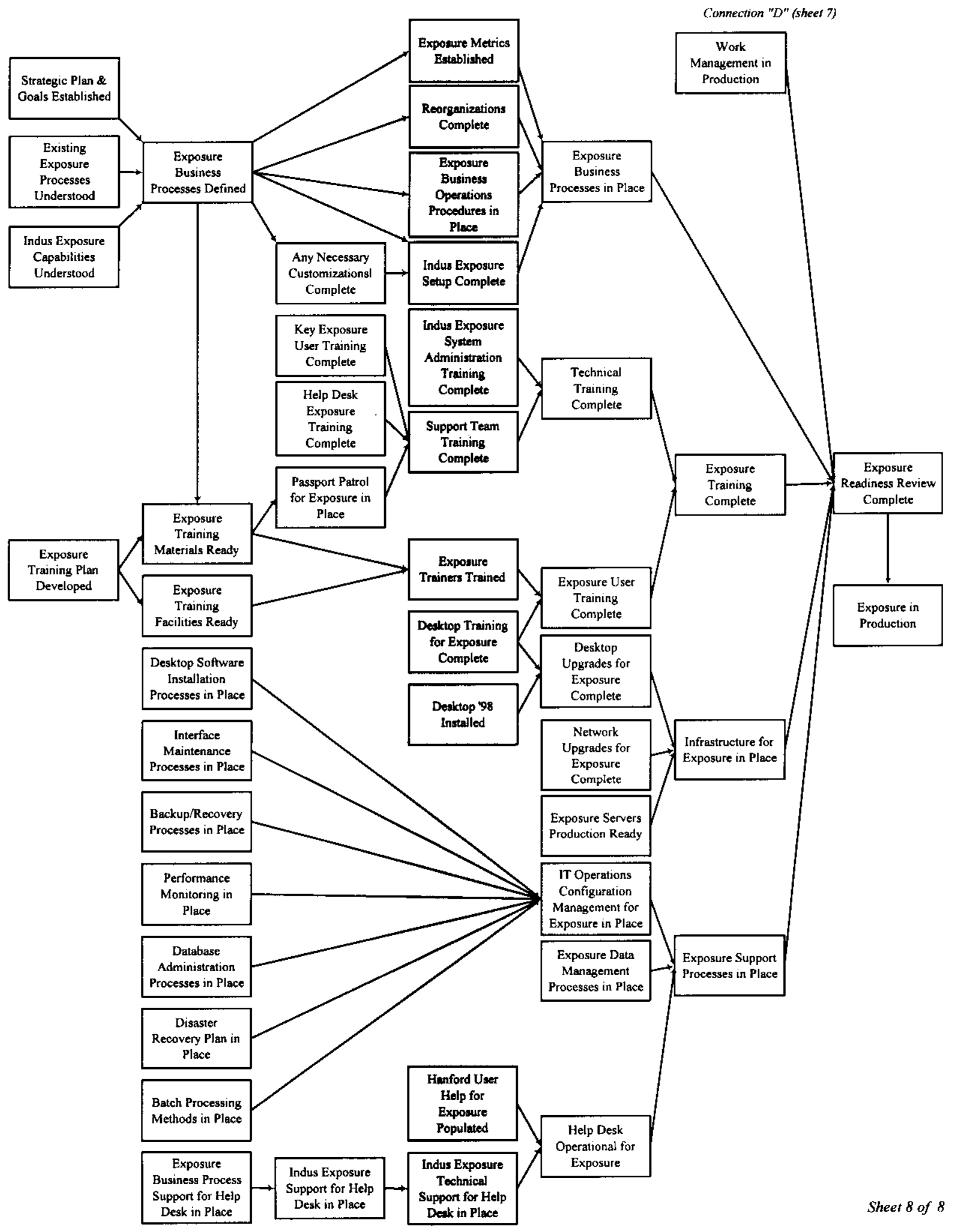

Exposure Program Logic 
Project Name: HANDI 2000

Document Number: HNF-1743
Publication Date: November 5, 1997

Page: 50 of 63

Revision: 1

\section{Integration Product}

Central to the HANDI 2000 implementation strategy is vendor accountability for product integration. The contract placed with Indus includes their responsibility for integrating the commercial software provided by Indus, PeopleSoft, and Primavera. Indus' integration approach is to provide an integration product that maps like data between the three products. Indus provides the physical and logical linkages; the project establishes the user-defined data structures, loads data, and establishes the frequency of synchronization between databases.

\section{External Integration}

There are a number of existing applications that will not be replaced by HANDI 2000 but do interact with applications being replaced. In many cases these interactions are not well documented. As the detailed implementation is developed for each subproject, the analysis of the as-is condition and the design of the to-be state will establish integration requirements for external applications.

All of the commercial products being utilized support external integration via programming "hooks" know as Application Programming Interfaces (APIs). It will be the responsibility of the owners of the external applications to develop corresponding linkages from their applications to the HANDI 2000 APIs. 
Project Name: HANDI 2000

Document Number: HNF-1743
Publication Date: November 5, 1997

Page: 51 of 63

Revision: 1

\section{VENDOR SPECIFIC DOCUMENTS}

\section{Site Survey}

Implementation of enterprise-wide software has a potential impact on many areas of the Information Systems infrastructure. The Indus site survey is used to identify the technical requirements of, and potential technical impediments to, a successful implementation. The survey examines the present and planned network, desktop hardware and software strategy, existing server capacity, and technical skill sets of employees working to implement and maintain the system.

The Site Survey generates a list of technical issues that may impact the implementation and identifies steps that must be taken toward the resolution of each.

\section{Sizing Study}

System performance is one of the prime factors for satisfaction with any application software. It is especially important in the case of an enterprise-wide application such as HANDI 2000. Indus is contracted to conduct an assessment of our environment to develop an accurate projection of the production transaction load. From that transaction load projection, hardware requirements can be forecast and appropriate steps taken to insure that the required hardware is in place in time for the production rollout.

\section{Mobilization Plans}

The Mobilization Plan provides vendor recommendations regarding organization, resources and schedule. It forms the basis for starting early activities while the detailed planning proceeds. The Mobilization Plan is an overview of the implementation process that addresses the scope of the implementation so that it fits our specific environment.

It also identifies assumptions governing overall conduct of the implementation effort. These include the inter-relationship of reengineering and software installation, the premise that a baseline product strategy is being followed and the human engineering (ability to absorb change) aspects of complex enterprise system installations.

Key Elements of this plan are:

- Description of processes used in implementation

- Clear scope statement with responsibilities clearly assigned

- Preliminary schedule

- Preliminary estimate of budget 
Project Name: HANDI 2000

Document Number: HNF-1743
Publication Date: November 5, 1997

Page: 52 of 63

Revision: 1

Mobilization plans have been prepared for the following aspects of the project:

- Finance and Supply Chain

- Work Management

- Project Management

- Integration

\section{Product Documentation}

Product documentation is provided on CD-ROM media by the vendors. The following CD's have been provided:

- Abacus 3.1 - Documentation of the Indus product implementation methodology

- Passport Baseline Documentation Release 6.0.1 - Product descriptions for each module, data models, system administration guide, technical support workbenches, data migration information, and product specifications.

- PeopleSoft Version 7 - Hypertext walkthroughs of product functions, report structures, and training guides.

- Passport-PeopleSoft Integration - Advance copy of the specification and default values for the integration product linking Indus Passport with PeopleSoft Financials. 
Project Name: HANDI 2000

Document Number: HNF-1743
Publication Date: November 5, 1997

Page: 53 of 63

Revision: 1

\section{PROJECT CLOSEOUT}

\section{Closeout Activities}

The project is composed of several sequential subprojects; these closeout activities are iterative for each subproject with a final closeout for the overall project. Closeout consists of three phases: Establishing an ongoing operations capability with will receive functional responsibility for the finished product; conducting acceptance testing and actually turning the product over; and closing out the residual project functions. The closeout planning will be completed as part of the detailed process definition. Process redesign will not be considered complete until the acceptance and closeout process is documented.

\section{Establish Ongoing Operations Capability}

This phase of the closeout establishes the organizational responsibility for accepting and operating the finished product. It is completed when the following four activities are complete:

- Establish ownership for the continuing funding and operation of the HANDI 2000 system.

- Move configuration control for the system from the project into the operations unit.

- Establish any needed contractual relationships with the individual software suppliers (Indus, PeopleSoft, and Primavera) for ongoing maintenance and support.

- Turn training resources over to the owner in order to support ongoing training activities.

\section{Acceptance/Turnover}

This phase of the closeout consists of the project and the owner establishing the acceptance criteria for product turnover, developing a mutually agreeable test and acceptance process, executing the test, resolving discrepancies and agreeing to turnover.

\section{Closeout}

During this final phase of the project, the product has been turned over to the owner and the project personnel closeout the following residual activities:

- Closeout all contracts for product delivery, support and installation.

- Complete all project records and place them in appropriate records storage.

- Release any remaining temporary staff.

- Reassign any permanent staff to new assignments. 
Project Name: HANDI 2000

Document Number: HNF-1743
Publication Date: November 5, 1997

Page: 54 of 63

Revision: 1

\section{HUMAN RESOURCES PLAN}

Introduction

The purpose of this plan is to describe the processes and the facilities to be used in deploying and training personnel affected by the work process changes resulting from the HANDI 2000 project to help them transition to the work environment resulting from those changes.

Areas covered by this plan:

- Structure of new work environment

- Development of job descriptions

- Job application and selection process

- The People Center

- Communication

- Use of the ABACUS training survey

- Philosophy of training for the HANDI 2000 project

- Schedule for development of the training plan

- Contents of the plan

\section{STRUCTURE OF NEW WORK ENVIRONMENT}

The re-engineering associated with implementing an unmodified COTS system creates a new work structure. Rather than managers monitoring the work of a functional area. there will be owners of processes that cut across several functions. Process Owners will be senior individuals with the accountability for all aspects of their process, from end to end.

Processes are those activities that produce an output that achieves the company's mission. Finance, procurement, work management are not processes. They are functions that contribute to the success of processes. The business processes that were built into the software that HANDI 2000 is comprised of are crosscutting. 
Project Name: HANDI 2000

Document Number: HNF-1743
Publication Date: November 5, 1997

Page: 55 of 63

Revision: 1

The result will be a matrixed organization as depicted in the example below:

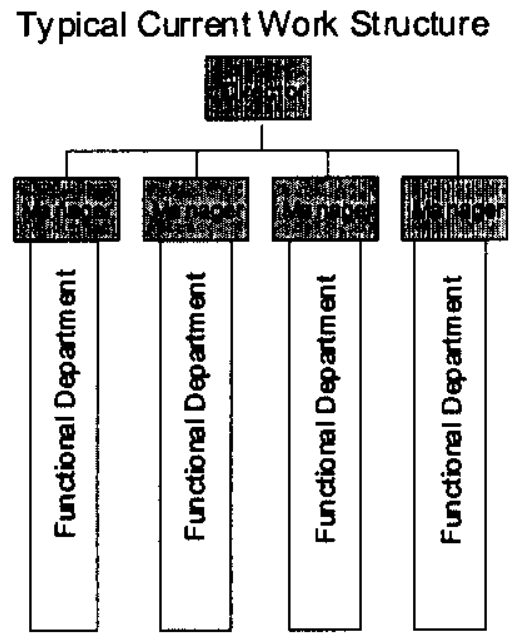

Work Structure After Process Redesign

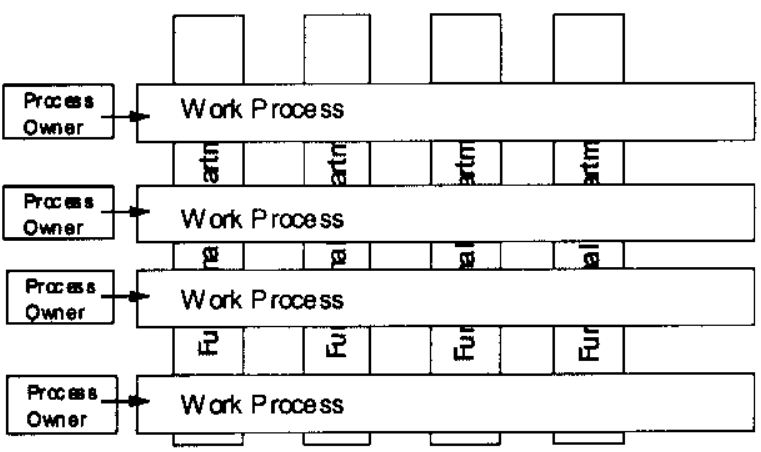

\section{DEVELOPMENT OF JOB DESCRIPTIONS}

The business process improvement sessions facilitated by the software vendor are the beginning of re-engineering. From the BPI sessions and the resolution of issues arising from them, the new work process emerges. As the new work process is clarified, job descriptions can be written for the new positions.

\section{JOB APPLICATION AND SELECTION PROCESS}

Once the job positions needed for by the new work processes are identified and the job descriptions written, the people currently working in the area will have to apply for the new positions. The old jobs literally will be abolished under the re-engineered system. The Human Resources (HR) Department will be involved, adding new "attributes" into traditional, technical job descriptions. Initiative, judgment, teamwork skills, leadership, decision-making ability, and customer focus are to be added to job description for non-bargaining unit positions (positions where employees are not represented by unions). Even for bargaining unit positions where job descriptions stay the same, personnel's work scope will change to include helping to prepare work packages instead of simply executing work packages.

HR involvement in designing the new job descriptions will specifically be focused on four areas: selection, compensation, performance measurements, and re-deployment of excess workers. Salaries will be placed in "broad bands" for the new positions, so that in no cases will people's individual salaries immediately change. Bands may be as simply as management, professional, salaried non-exempt, and bargaining unit. 
Project Name: HANDI 2000

Document Number: HNF-1743
Publication Date: November 5, 1997 Page: 56 of 63

Revision: 1

New job positions will be posted in a "People Center" newsletter and at some ancillary locations. The application time will be limited to two weeks, with only current employees from a specific area able to apply for the new positions. Applicants will be asked to list their first, second and third choices for placement on teams. Employees will be encouraged to list not just jobs most closely fitting their current job, but additional jobs that might use skills not previously recognized or exercised. A Selection Committee will be chosen to review the applications and to pick people for each of the positions. The Selection Committee should consist of a HR representative, the HANDI 2000 Re-engineering Director, the Director of the functional area, the Process Owner and one or two other related individuals. The interviewing and selection process will take approximately two weeks.

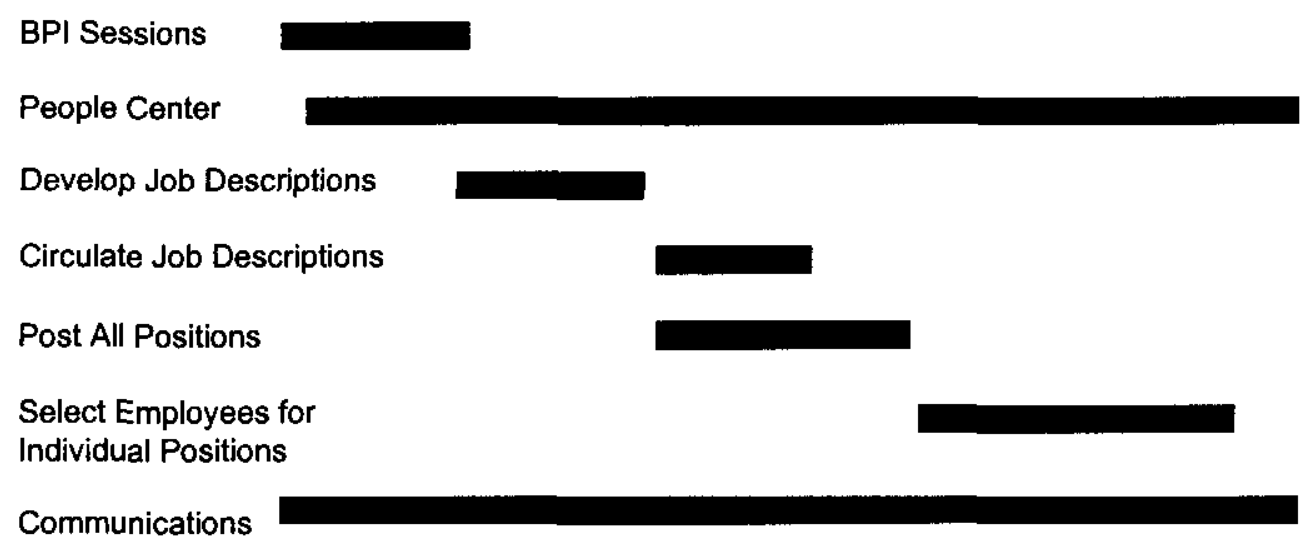

\section{THE PEOPLE CENTER}

A "People Center" will be established, initially in 2355 Stevens, to address the substantial changes that are anticipated from the full HANDI 2000 implementation. People Center's have been successfully used in re-engineering efforts at PUREX and B-Plant.

The magnitude of the changes approaching employees necessitates some positive steps be taken to address the changes. A Task Team consisting of an organizational development specialist, a communications specialist, and representatives of many job categories (management, exempt, salaried non-exempt, and bargaining unit). The key missions for the Center will be communications and job placement information and services. The crucial difference between the People Center and traditional HR services will be that the Center will be available well before people are officially issued notices of impending termination. providing direct access to all Human Resources services; timely information about the project, site and external information; and by giving employees opportunities to help prepare themselves for employment at the completion of the project. Placement efforts for people whose work will actually end will be 
Project Name: HANDI 2000

Document Number: HNF-1743
Publication Date: November 5, 1997

Page: 57 of 63

Revision: 1

aimed outward in a widening circle first on the Hanford Site, then in the Hanford region, and then in the larger Pacific Northwest region.

To enable the People Center to function optimally it will be staffed full-time (but on a rotational basis) so that employees can have access to it whenever they feel most anxious. The anticipated benefits of the People Center are enhanced project stability; giving employees access to accurate information about the Hanford Site and about HANDI 2000; providing employees access to career pathing tools; sharing information to enable employees to make intelligent career decisions; allowing employees a place to talk and a person to talk to; providing confidential counseling; and limiting or preventing unfounded rumors. The Center should offer HR Job Placement services (Internet connections and other computer links, voice mail services, pointsof-contact lists from local agencies, forms, procedures, union contacts and contracts, union seniority lists); assistance in writing resumes; books, audio tapes and video tapes on the interview process; bibliographies of resources from the local college and university; and contact with coordinators and specialists in Employee Concerns (a grievance program), organizational development, and communications.

\section{COMMUNICATION}

A People Center newsletter, or column in existing HANDI 2000 newsletters, will be started immediately. Also in view of people's different learning styles, Employee Meetings should be held on a monthly basis with employees in the affected areas so that people could hear the project news verbally. All employee bulletins will also be used to provide specific information.

\section{THE TRAINING PLAN}

As BPI sessions end and larger group re-engineering occurs is will be necessary to provide people with ongoing training in how to function in new modes. Training, based on DDI vendorsupplied, commercial modules will be used in the four fields of teaming skills, communication skills, leadership, and problem solving. Additionally, a self-directed video course will be available to assist process teams to understand their work culture and basic roles and responsibilities that may act as a "Team Start-up Kit".

\section{USE OF THE ABACUS TRAINING SURVEY}

The ABACUS training survey is a template that will be used for developing the training plan. Then the template is followed and the survey complete, the training plan document will be developed. The ABACUS template training survey is attached.

\section{PHILOSOPHY}

There are four areas that will be addressed in the training plan:

- Job skills/software/job process training 
Project Name: HANDI 2000

Document Number: HNF-1743
Publication Date: November 5, 1997

Page: 58 of 63

Revision: 1

- Transition/change/stress management training

- Teaming/cultural skills training

- Management leadership training

Each of these areas is important and must be considered essential for a successful transition.

\section{SCHEDULE FOR DEVELOPMENT OF TRAINING PLAN}

Completion of the training survey and writing of the training plan should take approximately 4 weeks. Concurrent with that activity, determination of the appropriate DDI courses will occur and be included in the final plan.

\section{CONTENT OF THE PLAN}

The plan will contain information about:

*Facilities and infrastructure

*Method of delivery

* Levels of training

*Outline for education plans (types of classes, curricula, end-user programs)

*Communication plans

*Post implementation and ongoing support 
Project Name: HANDI 2000

Document Number: HNF-1743
Publication Date: November 5, 1997

Page: 59 of 63

Revision: 1

\section{GLOSSARY AND TERMS}

AS-IS - The product of a process to baseline an existing process; to identify and document performance gaps in process cost, cycle time, product quality, and organizational and technological issues, in order to develop process improvement opportunities

Baseline - The original plan (for a project, a work package, or an activity) plus or minus approved changes. Usually used with a modifier, e.g., cost baseline, schedule baseline, performance measurement baseline, etc.

Business Process - A set of logically related tasks performed to achieve a defined business outcome.

Business Process Improvement - A process that redesigns work processes to take advantage of the best business practices around which the ERP software is designed.

Change Control - Change control is the process by which changes to the technical, cost, and schedule baselines are managed.

Configuration Management - An integrated management process and program that establishes consistency among requirements, basis, functional configuration, physical configuration, and documentation, allocates requirements and maintains and controls consistency throughout the life of the product as changes occur.

Control - The process of comparing actual performance with planned performance, analyzing variances, evaluating alternatives, and taking appropriate corrective action as needed.

HANDI 2000 - FDH Project with the scope of implementing an enterprise resource planning solution and identifying and resolving the Hanford site year 2000 issues.

Enterprise Resource Planning (ERP) - Integrated software packages purchased from Indus and PeopleSoft.

Integration - determining all the interactions between the diverse functional and organizational aspects of site activities, and unifying as a whole by incorporating those interactions into planning, decision making, and execution.

Other Hanford Contractors - DOE contractors that are not part of the PHMC Team.

PHMC Team - FDH and its subcontractors.

Product - Indus Passport and PeopleSoft integrated software. 
Project Name: HANDI 2000

Document Number: HNF-1743
Publication Date: November 5, 1997

Page: 60 of 63

Revision: 1

Project - An activity or series of activities related to the accomplishment of a clear goal, with a beginning, a middle, and an end to the efforts, and with defined lines of authority and responsibility, scope of work, and budget with change control.

Site - Synonymous with 'Hanford'. Use of these terms shows FDH's involvement in Hanford activities to the extent authorized by the PHMC.

Subproject Managers - Project Managers reporting to the H2K Project Director, responsible for full implementation of assigned ERP software modules.

TO-BE - A product of the business process improvement process by which business rules are defined and Indus Passport and PeopleSoft implementation preferences are set.

Year 2000 (Y2K) Project - FDH Project with the scope of mitigating the sites year 2000 issues

Year 2000 Issues - For decades, expensive data storage was minimized by storing the Year as two digits (97) without the century, instead of four digits (1997). As a results some computer store the Year 2000 date as 00 . Many computer systems will interpret 00 as the Year 1900 rather than the Year 2000 resulting in unpredictable behavior or inoperability.

Customizations - items considered customizations to the PeopleSoft and Indus baseline products:

Modifications to vendor supplied software:

- Adding, removing or changing executable code

- Removing or changing SQR code

- Removing or changing reports generated from within the software package

Modifications to the user interface:

- Adding new menu items or changing vendor supplied menu items

- Adding new panels or changing vendor supplied panels

- Adding, removing or changing fields on a panel

- Adding a Passport rule to a panel

Modifications to the database:

- Adding or removing a table in the database

- Adding or removing a field in a table

- Changing the attributes of a field 
Project Name: HANDI 2000

Document Number: HNF-1743

Modifications to data values:

- Using a field for which it was not intended

- Changing default values for a field *

- Adding or changing data input edits
Publication Date: November 5, 1997

Page: 61 of 63

Revision: 1

Items not Considered Customizations to the Baseline Products:

- Reports developed by user organizations

- Reports, including SQR or Crystal Reports, created for the customer by LMSI or other services providers

- Adding user defined fields or values to a delivered database process *

- Setting standard product preferences and setup parameters *

* Configuration Control of User Configurable Parameters

As part of the baseline products, undefined database fields are provided to allow organizations the flexibility of capturing data needed to support business processes without making changes to the database structure. Many of the fields are provided with default values that can be configured by the implementing organization. The products also allow the implementing organizations to select options for process flows and overall system configuration. Establishing the values and preferences for these types of options is not considered customization.

Once those decisions have been made however, the implementation comes under configuration control. Further changes, while not considered customizations, do require the concurrence of the change board. 